\title{
Ground-Water Data for the Nevada Test Site and Selected Other Areas in South-Central Nevada, 1992-93
}

\section{U.S. GEOLOGICAL SURVEY}

Open-File Report 95-160

Prepared in cooperation with the NEVADA OPERATIONS OFFICE, U.S. DEPARTMENT OF ENERGY, under Interagency Agreement DE-AI08-86NV10583

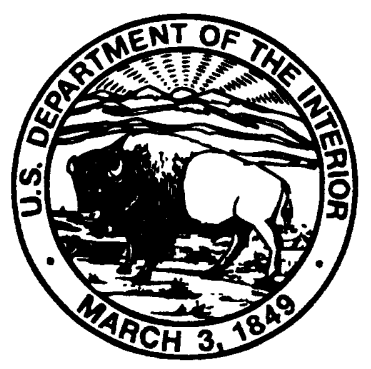




\title{
U.S. DEPARTMENT OF THE INTERIOR BRUCE BABBITT, Secretary
}

\author{
U.S. GEOLOGICAL SURVEY \\ GORDON P. EATON, Director
}

Any use of trade names in this publication is for descriptive purposes

only and does not constitute endorsement by the U.S. Government

For additional information write to:

District Chief

U.S. Geological Survey 333 West Nye Lane, Room 203

Carson City, NV 89706-0866
Copies of this report can be purchased from:

U.S. Geological Survey

Information Services

Box 25286, MS 517

Denver Federal Center

Denver, CO 80225-0046 


\section{CONTENTS}

Abstract

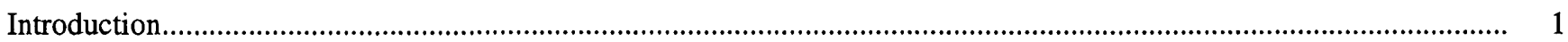

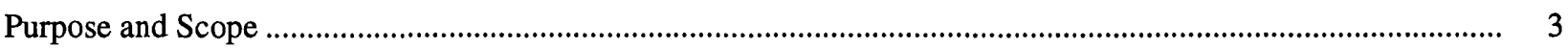

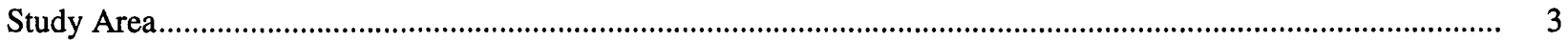

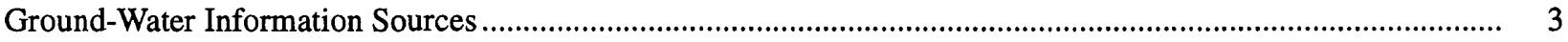

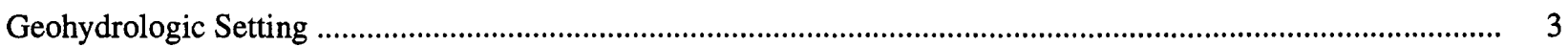

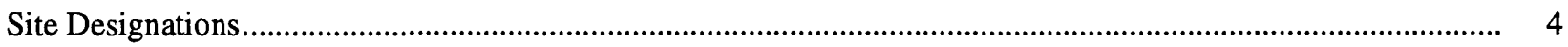

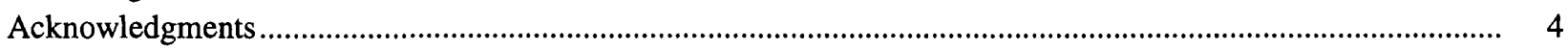

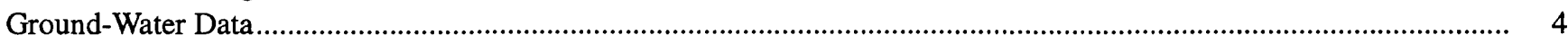

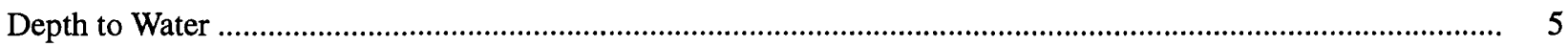

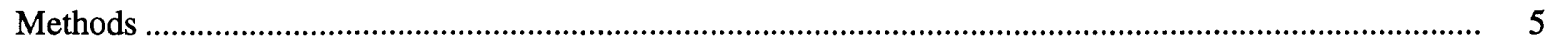

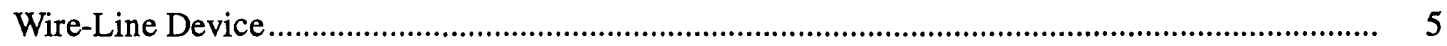

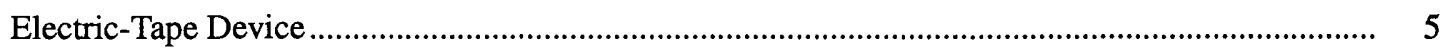

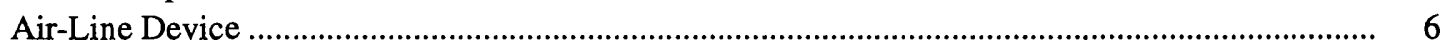

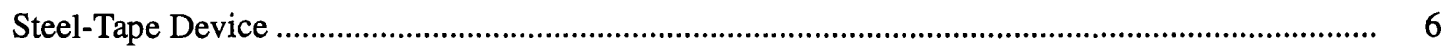

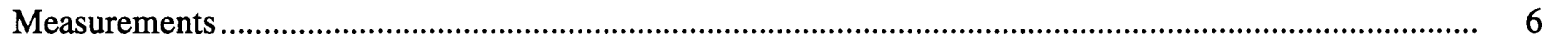

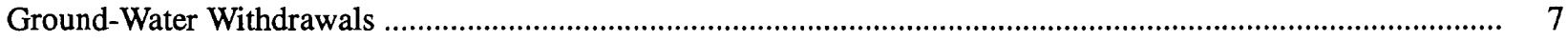

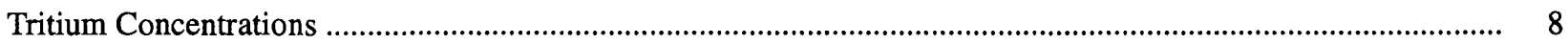

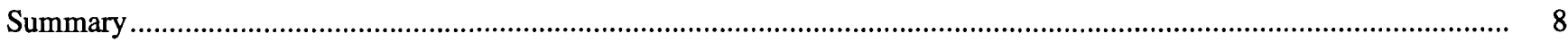

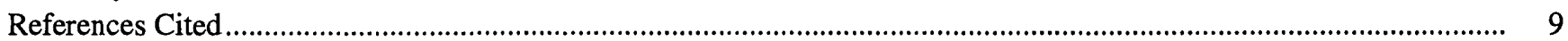

\section{PLATE}

1. Map showing location of wells and test holes at Nevada Test Site and vicinity, south-central Nevada

\section{FIGURES}

1. Map showing location of Nevada Test Site and vicinity, including Faultless Site ............................................. 2

2. Map showing location of test holes at Faultless Site, Nye County, Nevada ......................................................... 3

3-11. Hydrographs showing depth to water through water year 1993 at Nevada Test Site in:

3. Well TW-7 in Yucca Flat hydrographic area(Area 3)

4. Test hole U-3cn 5 in Yucca Flat hydrographic area (Area 3)

5. Test hole UE-3e 4 in Yucca Flat hydrographic area (Area 3) .....................................................................

6. Test hole UE-5n in Frenchman Flat hydrographic area (Area 5) .............................................................. 14

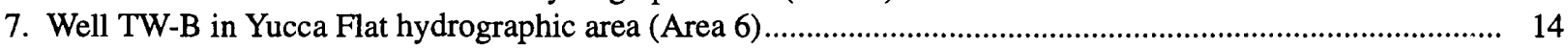

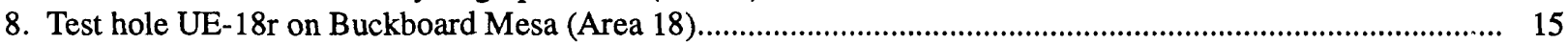

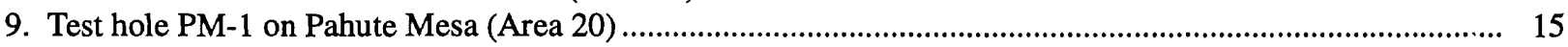

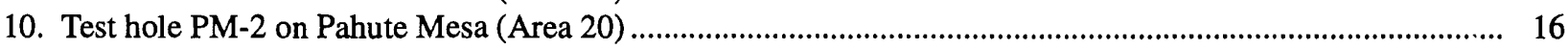

11. Well TW-F in Frenchman Flat hydrographic area (Area 27) ................................................................... 16

12-17. Hydrographs showing depth to water through water year 1993 in vicinity of Nevada Test Site in:

12. Test hole HTH-1 in Hot Creek Valley hydrographic area......................................................................... 17

13. Test hole UC-1-P-2SR in Hot Creek Valley hydrographic area................................................................ 17

14. Well Army 2 in Indian Springs Valley hydrographic area ................................................................... 18

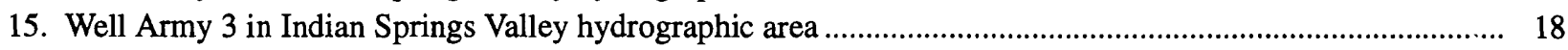

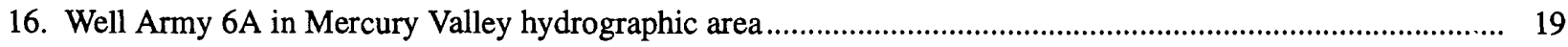

17. Test hole PM-3 in Oasis Valley hydrographic area ......................................................................... 19

18. Graph showing annual ground-water withdrawals from Nevada Test Site, 1984-93 ......................................... 20

19. Graph showing monthly ground-water withdrawal from Nevada Test Site, 1993 ............................................ 20 


\section{TABLES}

1. Depth to water in wells and test holes at Nevada Test Site, Nye County, Nevada .................................................... 21

2. Depth to water in wells and test holes in vicinity of Nevada Test Site, Nye and Clark Counties, Nevada.................... 29

3. Monthly and annual ground-water withdrawals in 1993 from wells at Nevada Test Site, Nye County, Nevada ............ 33

4. Tritium concentrations in water samples from test holes at and in vicinity of Nevada Test Site, Nye and Clark

Counties, Nevada

\section{CONVERSION FACTORS AND VERTICAL DATUM}

\begin{tabular}{rll}
\hline Multiply & By & To obtain \\
\hline becquerel $(\mathrm{Bq})$ & 27.027 & picocurie \\
kilometer $(\mathrm{km})$ & 0.6214 & mile \\
liter $(\mathrm{l})$ & 0.2642 & gallon \\
meter $(\mathrm{m})$ & 3.281 & foot \\
million liters & 0.2642 & million gallons \\
square kilometer $\left(\mathrm{km}^{2}\right)$ & 0.3861 & square mile \\
\hline
\end{tabular}

Sea level: In this report, "sea level" refers to the National Geodetic Vertical Datum of 1929 (NGVD of 1929, formerly called "Sea-Level Datum of 1929"), which is derived from a general adjustment of the first-order leveling networks of the United States and Can ada.

Water Year: Comprises the 12-month period from October 1 through September 30, and is designated by the year in which the period ends. 


\title{
Ground-Water Data for the Nevada Test Site and Selected Other Areas in South-Central Nevada, $1992-93$
}

\author{
By Steven R. Reiner, Glenn L. Locke, and Leanne S. Robie
}

\section{ABSTRACT}

The U.S. Geological Survey, in support of the U.S. Department of Energy Environmental Restoration and Hydrologic Resources Management Programs, collects and compiles hydrogeologic data to aid in characterizing the regional and local ground-water flow systems underlying the Nevada Test Site and vicinity. This report presents selected ground-water data collected from wells and test holes at and in the vicinity of the Nevada Test Site.

Depth-to-water measurements were made during water year 1993 at 55 sites at the Nevada Test Site and 43 regional sites in the vicinity of the Nevada Test Site. Depth to water ranged from 87.7 to 674.6 meters below land surface at the Nevada Test Site and from 6.0 to 444.7 meters below land surface at sites in the vicinity of the Nevada Test Site. Depth-to-water measurements were obtained using the wire-line, electric-tape, air-line, and steel-tape devices.

Total measured ground-water withdrawal from the Nevada Test Site during the 1993 calendar year was 1,888.04 million liters. Annual ground-water withdrawals from 14 wells ranged from 0.80 million to 417.20 million liters. Tritium concentrations from four samples at the Nevada Test Site and from three samples in the vicinity of the Nevada Test Site collected during water year 1993 ranged from near 0 to 27,676.0 becquerels per liter and from near 0 to 3.9 becquerels per liter, respectively.

\section{INTRODUCTION}

The Nevada Test Site (fig. 1) was establisl $\odot d$ in 1950 as a continental proving ground for testing nuclear weapons. Atmospheric nuclear testing began in 1951 and underground nuclear testing began in 1957. Since 1962, all nuclear testing has been done urderground, primarily in alluvium and volcanic rocks (U.S. Geological Survey, 1976, p. 17). Nuclear testing and ancillary operations at the Nevada Test Site (NTS) have created the potential for contamination of groundwater supplies by radionuclides and other substances (U.S. Department of Energy, 1990, p. 110).

The U.S. Department of Energy (USDOE) is required to study potential ground-water contamination at NTS and, through its Environmental Restoration Program, has begun to define possible contamiration resulting from past activities at NTS. The mission of the USDOE Hydrologic Resources Management Program is to ensure that current activities proceed in an environmentally sound manner and in accordance with applicable Federal and State regulations and USDOE orders. The U.S. Geological Survey (USGS) provides hydrologic expertise and technical guidance to the USDOE in support of these programs. Specific responsibilities of the USGS include providing the nec?ssary hydrologic and hydrogeologic data and interpretation of these data to aid in characterizing ground-water flow at the NTS and vicinity. This characterization is needed to assess the potential for contamination of groundwater supplies and to support USDOE operations at NTS. 


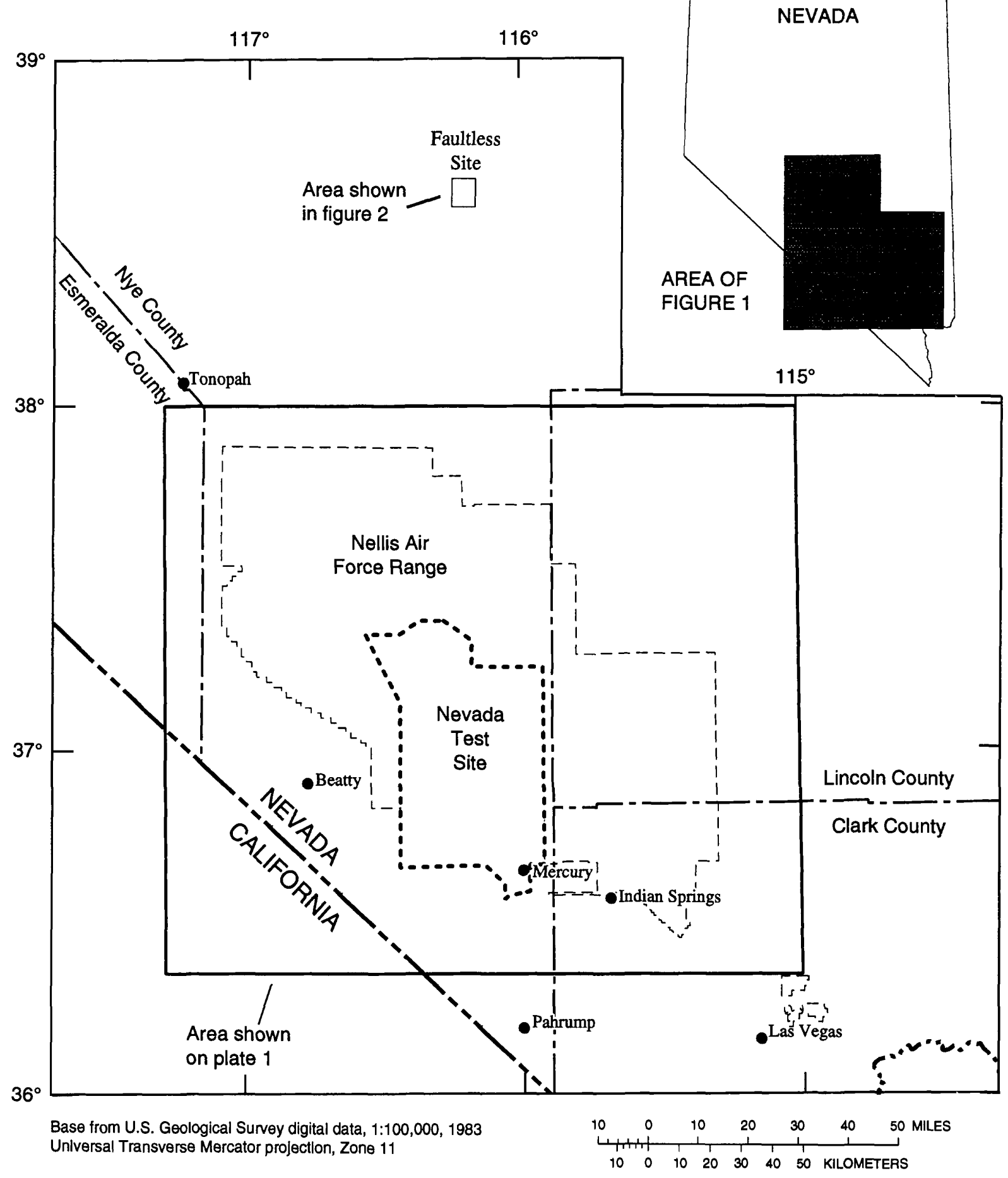

Figure 1. Location of Nevada Test Site and vicinity, including Faultless Site. 


\section{Purpose and Scope}

This report presents ground-water data collected at NTS and selected other areas in south-central Nevada. Depth-to-water measurements made during water year 1993 at 55 wells and test holes at NTS and 43 wells and test holes in south-central Nevada are presented. Ground-water withdrawal data are compiled for 14 wells at NTS during the 1993 calendar year. Water samples from four wells and test holes at NTS and from three wells in the vicinity of NTS were collected and analyzed during the 1993 water year.

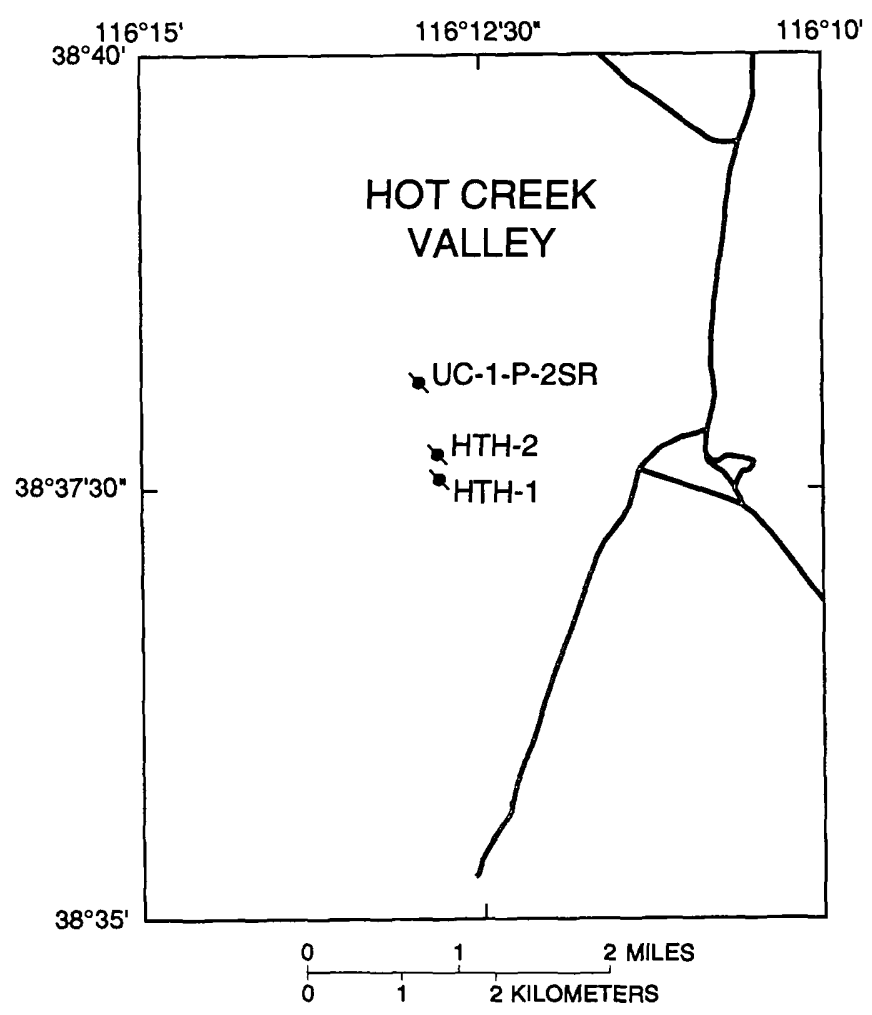

EXPLANATION

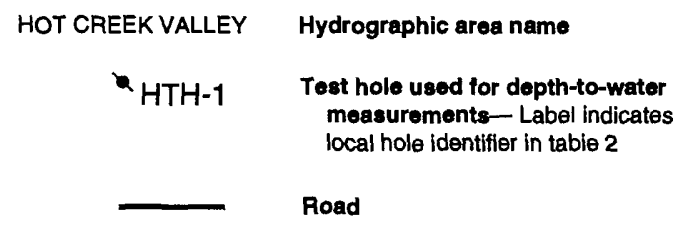

Figure 2. Location of test holes at Faultless Site, Nye County, Nevada.

\section{Study Area}

NTS is subdivided into 27 administrative areas between latitudes 36 and 38 degrees north and longitudes 115 and 117 degrees west within Nye County, Nev. (fig. 1, pl. 1). Regional ground-water site in the vicinity of NTS are between latitudes 36 and 39 degrees north and longitudes 115 and 117 degrees west within Clark and Nye Counties, Nev. (fig. 1, pl. 1). The Faultless Site in Hot Creek Valley is between latitudes 38 and 39 degrees north and longitudes 116 and 117 degrees west within Nye County, Nev. (figs. 1, 2).

\section{Ground-Water Information Sources}

Depth-to-water data at and in the vicinity of NTS have been collected, compiled, verified, and stored in the Ground-Water Site Inventory (GWSI) data base by the USGS in support of the USDOE Environm ${ }^{n}$ tal Restoration and Hydrologic Resources Management Programs. This GWSI data base is one of four subsystems that constitute the computerized National Water-Information System (NWIS) of the USGS (U.S. Geological Survey, 1989).

Other ground-water data were compiled and reported by the USGS Hydrologic Investigation and USGS Environmental Monitoring Programs, Yucca Mountain Project (Luckey and others, 1989; O'Brien, 1991; La Camera and Westenburg, 1994). Groundwater withdrawal data for two wells in Area 25 (J-12 WW and J-13 WW) are included in this renort to account for total withdrawal from NTS.

\section{Geohydrologic Setting}

The geohydrologic setting of NTS is characterized by local aquifers of alluvium of Quaternar.' and Tertiary age and volcanic rock of Tertiary age. Regional aquifers are mainly complex folded and faulted carbonate rock of Paleozoic age (Winocrad and Thordarson, 1975, p. 14-31), but deep, fractured volcanic rock of Tertiary age also may be regional aquifers at some locations (Blankennagel and V'eir, 1973, p. 6). Regional confining units are mainly clastic rock of Paleozoic age and some volcanic rock $c^{f}$ Tertiary age. Much of the ground-water movement is 
regional interbasin flow, which is not controlled by the basin-and-range topography that defines the local surface drainage basins (Winograd and Thordarson, 1975, p. 62).

Ground water at NTS and vicinity is part of the Death Valley ground-water flow system, a regional system encompassing $38,800 \mathrm{~km}^{2}$. NTS includes parts of three subbasins of the Death Valley ground-water flow system-Alkali Flat-Furnace Creek Ranch, Ash Meadows, and Oasis Valley (Waddell and others, 1984, p. 36-39; R.J. Laczniak, U.S. Geological Survey, written commun., 1995; pl. 1).

\section{Site Designations}

Ground-water sites in this report are either wells or test holes: wells are cased holes drilled specifically to find ground water; test holes are all other drilled holes. Wells and test holes at NTS and vicinity are identified herein by Raytheon Services Nevada (RSN) hole number or local well identifier, by USGS standard identification number, and by the latitude and longitude of the site.

Hole numbers are assigned by RSN to wells and test holes according to the type of hole drilled, site location (NTS administrative area), and sequence code for the consecutive order in which the hole was drilled or redrilled. Emplacement holes drilled for proposed nuclear testing events begin with the letter "U," followed by a dash (-), NTS area number, and sequence code (letters "a-z, aa-az, ba-bz,..., za-zz"). Exploratory holes, drilled to assess material properties within a defined area, follow the same naming convention but begin with the letters "UE." The suffix letters "PS" indicate a post-shot hole drilled to monitor radionuclides and the effects of nuclear testing events; "S," a substitute hole drilled to replace an emplacement or exploratory hole; and "WW," a water well drilled as a potential water-supply source.

Exceptions to the standard naming convention are PM-1, PM-2, RNM-2S, TW-1, TW-7, TW-B, TWD, TW-F, WW-2, WW-3, WW-4, WW-4A, WW-5A, and WW-5C. The prefix letters "ER," indicate environmental restoration; "PM," Pahute Mesa; "RNM," radionuclide migration; "TW," test well; and "WW," water well. Numbers and letters following the dash in these exceptions represent sequence of site drilling, not NTS area location.
Local hole identifiers for wells and test holes in the vicinity of NTS are assigned by well owners or the USGS. These local hole identifiers may contain abbreviations that are the same as or similar to the ones found in RSN hole numbers for NTS wells and test holes. Abbreviations used in these hole identifiers that are not used at NTS include "DDL" for Desert Dry Lake, "DR" Desert Range, "HTH" hydrologir test hole, "TTR" Tonopah Test Range, "TPJ" Tolicha Peak Junction, "UC" underground central Nevada, anc "USAF" United States Air Force.

The USGS system for site identification is based on the latitude-longitude grid. Each site is identified by a unique 15-digit number; the first six digits are generally the degrees, minutes, and seconds of lat tude, the next seven digits are the generally the degrees minutes, and seconds of longitude, and the last two digits are the sequence number of the well or test hole within the 1second grid of latitude and longitude. The arsigned number is retained as a permanent identifier even if a more precise latitude and longitude are later determined (U.S. Geological Survey, 1989). To determine the geographic location of a well or test hole, the latitude and longitude coordinates should be used rather than the site identifier.

\section{Acknowledgments}

Raytheon Services Nevada and Atlas Wireline Services, contractors with the Nevada Operetions Office of USDOE, made substantial contributions to this report including field inventory of wells and test holes and other hydrologic work at NTS. Reynolds Electrical \& Engineering Co., Inc. (REECo) provided data on ground-water withdrawal. The Environmental Monitoring Systems Laboratory of the U.S. Environmental Protection Agency (USEPA) at Las Vegas did the tritium analyses. Personnel of Nellis an 1 Indian Springs Air Force Bases assisted in providirg access and construction data for many off-site wells.

\section{GROUND-WATER DATA}

Data presented consist of depth-to-wat $r$ measurements for accessible wells and test holes, compiled ground-water withdrawals for wells, and trit'im concentrations for wells and test holes. Depth tc water was measured in 98 wells and test holes, gro'und-water 
withdrawals were compiled for 14 wells, and tritium concentrations were determined for water samples collected from 7 wells and test holes.

Measurements were made in inch-pound units and converted to the International System of Units (SI). The number of significant figures was retained in each conversion. However, length measurements are reported to the nearest tenth of a meter to reflect the precision of field measurements.

\section{Depth to Water}

The term "depth to water" is used rather than "water level" to avoid confusion with "static water level" as defined by Winograd (1970, p. 19) for NTS. Use of depth to water does not imply static conditions.

Two networks of wells and test holes are measured-an NTS network and a regional network in the vicinity of NTS. Depth to water is measured intermittently in most of the accessible wells and test holes in these areas.

Measurements are made frequently in new wells and test holes until the depth to water stabilizes, the hole is destroyed, or the hole becomes inaccessible due to test site activities. Depth-to-water measurements in wells and test holes often represent elevated or depressed water levels caused by injection or removal of fluids during drilling operations or by nearby underground detonations (Winograd, 1970, p. 20-25). Because most of the existing wells and test holes available for long-term monitoring were not drilled for the acquisition of hydrologic data, construction may allow several saturated units to contribute water to the wells or test holes. Depth-to-water fluctuations may represent a composite water level for multiple saturated units rather than conditions within a single aquifer unit (alluvium, volcanic-rock, or carbonate-rock aquifers).

Water-level altitudes, determined by subtracting depth-to-water measurements from the reported landsurface altitude, should be used with caution. The reported altitude of land surface is usually determined when drilling operations are completed. However, subsequent NTS activities may alter the land-surface datum. Changes in land-surface altitude, measuring point, or both, may affect depth-to-water measurements and the calculated water-level altitude.

\section{Methods}

Several techniques are used to measure denth to water at NTS and other areas in south-central Nevada. Currently, measurements are made by the USGS with wire-line, electric-tape, air-line, and steel-tape d?vices.

The wire-line and electric-tape devices are calibrated at least annually against a reference steel tape. For these devices, a correction factor is determined to account for cable or tape stretch that occurs dur'ng measurement. The apparent depth-to-water measurement is adjusted by the correction factor to obtain the depth to water. Each device is calibrated at different depths over the useful range of measurement of the device. The reference steel tape is calibrated by procedures of the National Institute of Standards and Technology (Taylor and Opperman, 1986).

A measuring point is established for each well or test hole. The measuring point is a point on the well or test hole from which depth-to-water measure'nents are referenced. Measured depth to water is adjusted to land-surface datum by subtracting or adding the distance of the measuring point above or below land surface.

\section{Wire-LIne Device}

The wire-line device consists of an armore f fourconductor cable mounted on a motorized reel. The cable is centered over the hole with a hydraulic l' nom. Attached to the cable end is a probe that transmits an electric current to a meter at land surface when w'ater is contacted. A measuring wheel, over which the cable passes, measures the length of cable passed intc the hole below the measuring point. The measured depth to water below the measuring point is corrected for cable stretch and adjusted to land-surface datum.

\section{Electric-Tape Device}

The electric-tape device consists of a weighted electrical cable with two wire conductors expos?d on the leading end. When both conductors contact water, electrical continuity between the two conductors is made and a visual display, sound beeper, or both is activated. The measured depth to water below the measuring point is corrected for tape stretch and adjusted to land surface datum. 


\section{Air-Line Device}

The technique used for making air-line measurements of depth to water is described by Garber and Koopman (1968, p. 11-14). The top of the air-line tube is connected to a motor-driven air compressor. Air pressure is increased in the air-line tube until all water in the tube has been expelled. Pressure stabilizes as the forced air pressure gradient in the air-line tube decreases with increasing water pressure. Gage readings indicate the length of the column of water expelled from the air line, either directly in feet of water or indirectly through pressure readings. To calculate depth to water, the length of the column of expelled water is subtracted from the length of the air-line tube. Measured depth to water is adjusted to land-surface datum by subtracting or adding the distance of the airline reference point above or below land surface.

\section{Steel-Tape Device}

The technique used for making steel-tape measurements of depth to water greater than $305 \mathrm{~m}$ below land surface is described by Garber and Koopman (1968, p. 2-6) and by Robison and others (1988, p. 9-11). The steel tape, which is mounted on a motorized reel, is suspended in the hole a known distance below the measuring point so that the bottom end is below the water surface. The length of wetted tape is subtracted from the suspended length below the measuring point and adjusted to land-surface datum.

\section{Measurements}

Depth-to-water measurements at 55 wells and test holes at NTS made during water year 1993 are listed in table 1. Depth-to-water measurements for 43 wells and test holes in the vicinity of NTS made during water year 1993 are shown in table 2. Data are organized in table 1 first by NTS administrative area, then by RSN hole-number designation within each area. Data are organized in table 2 by Nevada hydrographic area (Rush, 1968) and then by local hole identifier. Tables 1 and 2 also include well location and construction information.

Depth to water ranged from 87.7 to $674.6 \mathrm{~m}$ below land surface at NTS and from 6.0 to $444.7 \mathrm{~m}$ below land surface at sites in the vicinity of NTS for water year 1993. All data have been entered into the GWSI data base. Pre-1993 and water year 1993 depthto-water measurements at and in the vicinity of NTS can be retrieved from the GWSI data base or found in previous publications (Wood, 1992; Robie and others, 1995).

The information available for some wells and test holes listed in tables 1 and 2 may be incomplate. Dates for which the month or day are unknown are listed as "00." Other information that is unknown or not applicable is identified with one or two dashes.

In this report, values for date hole completed and hole depth may disagree with values reporte $\mathrm{l}$ by RSN or other agencies. The date of hole completinn shown in tables 1 and 2 is the date when drilling activities that may have affected water levels ceased. The date of hole completion is not the reported date that all construction activities at the hole ceased. The ho'e depth is the most recently available measured or reported accessible depth. For some holes, the bottom of c ven interval listed in tables 1 and 2 may be deeper than the hole depth listed. This is because the bottom of open interval is reported at the time of well or test hole installation, whereas the hole depth is the latest accessible depth measured or reported.

The terms active testing area and inactive testing area refer to the approximate extent of areas where nuclear testing occurred. Active testing areas are areas where nuclear testing occurred during or after 1982 . Inactive testing areas are areas where nuclear testing occurred prior to 1982 .

Nine hydrographs for wells and test holes at NTS (figs. 3-11) and six hydrographs for wells in t 1 ? vicinity of NTS (figs. 12-17) show changes in depth to water with time. These selected hydrographs are f"om wells in several geographic areas and rock types. All available depth-to-water measurements for these hydrographs are displayed.

Depth-to-water measurements in well TW-7, which is in an active testing area in the Yucca Flat hydrographic area (Area 3, pl. 1), are shown in figure 3. The well is open to volcanic rocks of Tert ary age, primarily tuff. Two anomalous rises in water level (lesser depth to water) were recorded, one on June 12, 1962, and one on September 13, 1963. Thes s peaks coincide with two nuclear detonations. The Aardvark event was 307 m east of TW-7 on May 12, 1962. The Bilby event was $1,173 \mathrm{~m}$ east-southeast of $\mathrm{T} \cdot \mathrm{V}-7$ on September 13, 1963 (U.S. Department of Erergy, 1993).

Depth-to-water measurements in test hole U-3cn 5, which is in an active testing area in the Yucca Flat hydrographic area (Area 3, pl. 1), are shown in figure 4. The test hole is open to Paleozoic carl onate rock. 
Depth-to-water measurements in test hole UE-3e4, which is in an active testing area in the Yucca Flat hydrographic area (Area 3, pl. 1), are shown in figure 5. The site consists of three piezometers each open to Tertiary volcanic rock at different depths.

Depth-to-water measurements in test hole UE-5n, which is in an inactive testing area in the Frenchman Flat hydrographic area (Area 5, pl. 1), are shown in figure 6. The test hole is open to Quaternary alluvium.

Depth-to-water measurements in well TW-B, which is in an area of active testing in the Yucca Flat hydrographic area (Area 6, pl. 1), are shown in figure 7 . The well is open to Tertiary volcanic rock, primarily tuff.

Depth-to water measurements in test hole UE-18r, which is on Buckboard Mesa in the Fortymile Canyon hydrographic area (Area 18, pl. 1), are shown in figure 8. The test hole is open to Tertiary volcanic rock, primarily tuff.

Depth-to-water measurements in test hole PM-1, which is in an active testing area on Pahute Mesa in the Gold Flat hydrographic area (Area 20, pl. 1), are shown in figure 9. The test hole is open to Tertiary volcanic rock, primarily tuff and rhyolite.

Depth-to-water measurements in test hole PM-2, which is in an area of active testing on Pahute Mesa in the Gold Flat hydrographic area (Area 20, pl.1), are shown in figure 10 . The test hole is open to Tertiary volcanic rock, primarily tuff, rhyolite, and dacite. The cause of the water-level rise in May 1993 has not been determined, but the rise may represent a recharge event or direct infiltration into the annulus of the test hole (G.M. Russell, U.S. Geological Survey, oral commun., 1994).

Depth-to-water measurements in well TW-F in the Frenchman Flat hydrographic area (Area 27, pl. 1) are shown in figure 11. The well is open to Paleozoic carbonate rock, primarily dolomite.

Depth-to-water measurements in test hole HTH-1 in the Hot Creek Valley hydrographic area (fig. 2) are shown in figure 12. The test hole is open to Quaternary and Tertiary alluvium and Tertiary volcanic rock. The minimum depth-to-water measurement was on January 22,1968 , three days after a nuclear detonation-the Faultless event-on January 19, 1968. The Faultless event was 915 m northwest of HTH-1 (U.S. Department of Energy, 1993).

Depth-to-water measurements in test hole UC-1P-2SR in the Hot Creek Valley hydrographic area (fig. 2) are shown in figure 13. The test hole is open to rubble, consisting of Quaternary and Tertiary all ivium and Tertiary volcanic rocks, caused by the collanse of the cavity formed by the Faultless event (Garber, 1981, p. 207-209). The Faultless event was $91 \mathrm{~m}$ nortl aast of UC-1-P-2SR (U.S. Department of Energy, 1S 93 ). Decreases in depth to water from September 1974 to the present are attributed to infilling of the cavity (Thordarson, 1987, p. 15-16).

Depth-to-water measurements in well Army 2 in the Indian Springs Valley hydrographic area (pl. 1) are shown in figure 14. The well is open to Quaternary and Tertiary alluvium.

Depth-to-water measurements in well Army 3 in the Indian Springs Valley hydrographic area (pl. 1) are shown in figure 15. The well is open to Quaterncry and Tertiary alluvium.

Depth-to-water measurements in well Army 6A in the Mercury Valley hydrographic area (pl. 1) are shown in figure 16. The well is open to Paleozo'c clastic rocks.

Depth-to-water measurements in test hole PM-3 on Pahute Mesa in the Oasis Valley hydrographic area (pl.1) are shown in figure 17. The test hole is ofen to Tertiary volcanic rock, primarily tuff. Measurements prior to September 14,1988, were made when tr 9 hole depth was $502.0 \mathrm{~m}$. Measurements from September 21, 1988, through 1991 were made when the hole d?pth was $920.2 \mathrm{~m}$. Measurements from 1992 through 1993 were made from two piezometers installed in February 1992 at depths of 508.1 and $653.5 \mathrm{~m}$.

\section{Ground-Water Withdrawals}

Ground-water withdrawals at NTS were compiled for calendar year 1993. Withdrawals were measured by REECo at 14 pumping wells used for water supply at NTS. The compilation does not incluce ground water removed from other wells and test holes during drilling, hydrologic testing, or sampling activities.

Withdrawals were determined from flowmeter information. Each well is equipped with a totalizing flowmeter that is periodically read by REECo p?rsonnel. Differences between flowmeter readings provide the volume of ground water withdrawn during the period between readings. Flow rates were assurned to be constant during the period between readings. Daily withdrawal was computed from the total calculated volume of withdrawal. Flowmeter readings are accurate to the last thousand gallons pumped. 
Monthly and yearly ground-water withdrawals from wells at NTS during 1993 are shown in table 3. The table lists wells by ground-water flow system subbasin, NTS administrative area, and RSN hole number. Primary water yielding units and location and construction data also are listed in table 3.

Annual ground-water withdrawals from individual wells during 1993 ranged from 0.80 million liters to 417.20 million liters. Total measured ground-water withdrawal from NTS was $1,888.04$ million liters.

Ground water at NTS is withdrawn from alluvium, volcanic rock, and carbonate rock (table 3). Wells at NTS in the Alkali Flat-Furnace Creek Ranch subbasin withdrew ground water from volcanic rock and those wells at NTS in the Ash Meadows subbasin withdrew from all three rock units. About 52 percent of the Ash Meadows subbasin withdrawal was from carbonate rock, 25 percent from alluvium, 21 percent from volcanic rock, and 2 percent from a well open to both alluvium and volcanic rock. Wells at NTS in the Oasis Valley subbasin had no withdrawals.

Annual ground-water withdrawals at NTS from 1984 through 1993 are shown in figure 18. Total ground-water withdrawals decreased from 4,229.61 million liters in 1989 to $1,888.04$ million liters in 1993.

Monthly ground-water withdrawals at NTS during 1993 is shown in figure 19 . Monthly ground-water withdrawals ranged from 121.73 million liters in December to 227.18 million liters in August.

\section{Tritium Concentrations}

Raw, unfiltered water samples were collected from four wells and test holes at NTS and three wells in the vicinity of NTS by using a wire-line point sampler. Prior to sampling, the collection bailer was rinsed with 5-percent hydrochloric acid. The bailer was then rinsed with tap and deionized water, air dried, and used to remove approximately $2 \mathrm{~L}$ of water from the well or test hole. Samples were collected in 1-L glass bottles. The Environmental Monitoring Systems Laboratory of USEPA in Las Vegas, Nev., analyzed the samples for tritium concentration.

Location and construction information, sample collection depths, and tritium concentrations for the sampled wells and test holes are presented in table 4. This table lists wells and test holes at NTS by administrative area number, and wells in the vicinity of NTS by Nevada hydrographic area. Because some of the wells have not been completely developed for water-quality sampling use, tritium concentrations may be from residual drilling fluids or other fluids introduced during drilling, pumping, or water injection instead of representing water solely from the saturated zone.

Tritium concentrations ranged from near 0 to 27,676.0 Bq/L from four wells sampled at NTS and from near 0 to $3.9 \mathrm{~Bq} / \mathrm{L}$ from three wells sampled in the vicinity of NTS during water year 1993. An average annual concentration of $740 \mathrm{~Bq} / \mathrm{L}$ of tritium in drinking water is the maximum permissible limit estal lished by USEPA in Title 40, Code of Federal Regulations (1988). Tritium concentrations in one well, PM-2, at NTS exceeded this limit.

\section{SUMMARY}

The USGS, in support of the USDOE Invironmental Restoration and Hydrologic Resources Management Programs, collects and compiles hydrogeologic data to aid in characterizing the regional and local ground-water flow systems at NTS and vicirity. This report presents data on depth to water, grourd-water withdrawals, and tritium concentrations for selected wells and test holes.

Depth-to-water measurements were made at 55 sites at NTS during the 1993 water year and ranged from 87.7 to $674.6 \mathrm{~m}$ below land surface. Depth-towater measurements made at 43 regional sites in the vicinity of NTS during water year 1993 ranged from 6.0 to $444.7 \mathrm{~m}$ below land surface. Annual groundwater withdrawals from 14 wells at NTS during calendar year 1993 ranged from 0.80 to 417.20 million liters per well. Total annual ground-water withdraval from NTS was 1,888.04 million liters. Tritium concentrations of four ground-water samples collected at NTS during the 1993 water year ranged from near 0 to 27,676.0 Bq/L and exceeded established drinking water standards at one well. Tritium concentrations of three ground-water samples collected in the ricinity of NTS during the 1993 water year ranged from near 0 to 3.9 $\mathrm{Bq} / \mathrm{L}$ and did not exceed established drinl'ing water standards. 


\section{REFERENCES CITED}

Blankennagel, R.K., and Weir, J.E., Jr., 1973, Geohydrology of the eastern part of Pahute Mesa, Nevada Test Site, Nye County, Nevada: U.S. Geological Survey Professional Paper 712-B, $35 \mathrm{p}$.

Garber, M.S., 1981, A method for estimating effective porosity in a rubble chimney formed by an underground nuclear explosion in Geological Survey Research 1971: U.S. Geological Survey Professional Paper 750-C, p. 207-209.

Garber, M.S., and Koopman, F.C., 1968, Methods of measuring water levels in deep wells: U.S. Geological Survey Techniques of Water-Resources Investigations, book 8, chap. A1, 23 p.

La Camera, R.J., and Westenburg, C.L., 1994, Selected ground-water data for Yucca Mountain region, southern Nevada and eastern California: U.S. Geological Survey Open-File Report 94-54, 162 p.

Luckey, R.R, Lobmeyer, D.H., and Burkhardt, D.J., 1989, Water levels in continuously monitored wells in the Yucca Mountain area, Nevada, 1985-88: U.S. Geological Survey Open-File Report 91-493, 252 p.

O'Brien, G.M., 1991, Water levels in periodically measured wells in the Yucca Mountain area, Nevada, 1989: U.S. Geological Survey Open-File Report 91-178, 51 p.

Robie, L.S., Reiner, S.R., and Locke, G.L., 1995, Groundwater data for the Nevada Test Site, 1992, and for selected other areas in south-central Nevada, 19521992: U.S. Geological Survey Open-File Report 95 $284,48 \mathrm{p}$.

Robison, J.H., Stephens, D.M., Luckey, R.R., and Baldwin, D.A., 1988, Water levels in periodically measured wells in the Yucca Mountain area, Nevada, 1981-87: U.S. Geological Survey Open-File Report 88-468, 132 p.

Rush, F.E., 1968, Index of hydrographic areas in Nevada: Nevada Division of Water Resources, Information Report 6, 38 p.

Taylor, J.D., and Opperman, H.V., 1986, Handbook for the quality assurance of meteorological measurements: U.S. Department of Commerce, National Bureau of Standards, NBS Handbook 145, SOP 11, 16 p.
Thordarson, William, 1987, Hydrogeology of the Fa'ltless Site, Nye County, Nevada: U.S. Geological Su'vey Water-Resources Investigations Report 86-434乞, $40 \mathrm{p}$.

U.S. Department of Energy, 1993, Announced United States nuclear tests, July 1945 through December 1992: Nevada Operations Office, Office of External Affairs Report DOE/NV-209, Revision 13, 112 p.

-1990, Environmental restoration and waste maragement-Five year plan, fiscal years 1992-96: Washington, D.C., U.S. Government Printing Office, 622 p.

U.S. Environmental Protection Agency, 1988, Title 40, Section 141, Drinking Water Regulations: Federal Register, U.S. Code of Federal Regulations, v. 41.

U.S. Geological Survey, 1976, Field trip to Nevada Test Site: U.S. Geological Survey Open-File Report 76-313, 64 p. 1989, National Water Information System user's manual, v. 2, chap. $4-$ Ground-water site inven'ory system: U.S. Geological Survey Open-File Rerort 89-587, $293 \mathrm{p}$.

Waddell, R.K., Robison, J.H., and Blankennagel, R.I., 1984, Hydrology of Yucca Mountain and vicinity, Nevada-California-Investigative results through mid-1983: U.S. Geological Survey Water-Resources Investigations Report 84-4267, 72 p.

Winograd, I.J., 1970, Noninstrumental factors affect:ng measurement of static water levels in deeply buried aquifers and aquitards, Nevada Test Site: Ground Water, v. 8 , no. 2 , p. 19-28.

Winograd, I.J., and Thordarson, William, 1975, Hyd ־ogeologic and hydrochemical framework, south-central Great Basin, Nevada-California, with special reference to the Nevada Test Site: U.S. Geological Survey Professional Paper 712-C, $126 \mathrm{p}$.

Wood, D.B., 1992, Ground-water data collected at the Nevada Test Site and vicinity, Nye County, Nevada, water years 1988-89: U.S. Geological Survey OpenFile Report 92-130, 50 p. 


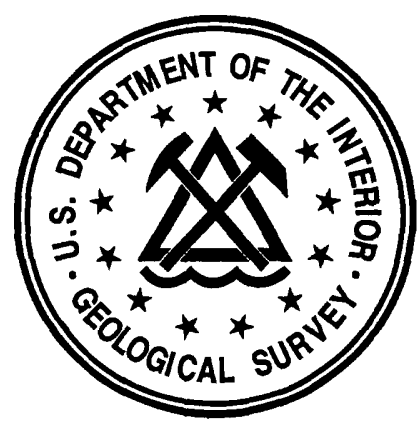


BASIC DATA 


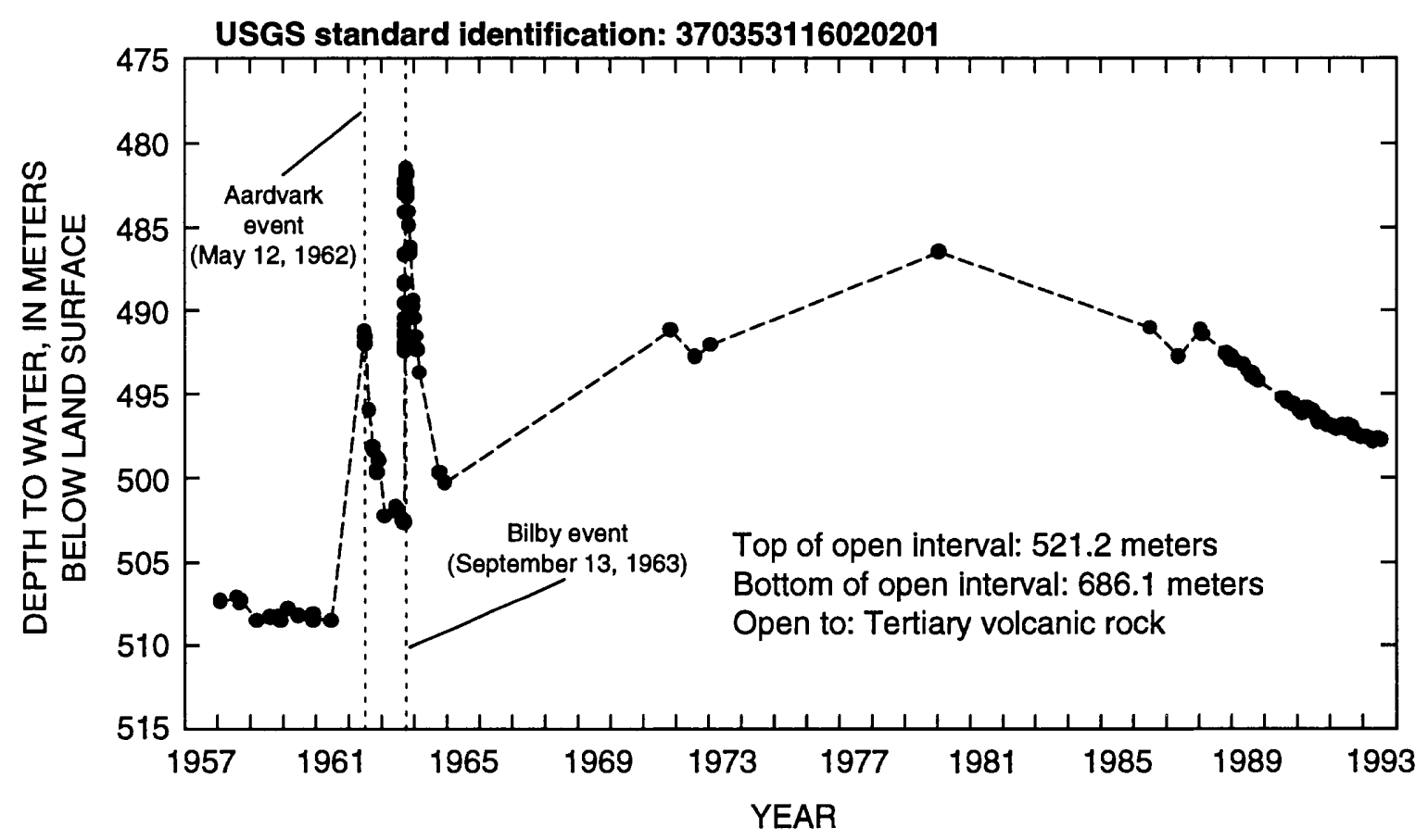

Figure 3. Depth to water through water year 1993 in well TW-7 in active testing area in Yucca Flat hydrographic area (Area 3), Nevada Test Site. Names and dates are indicated for nearby weapons tests.

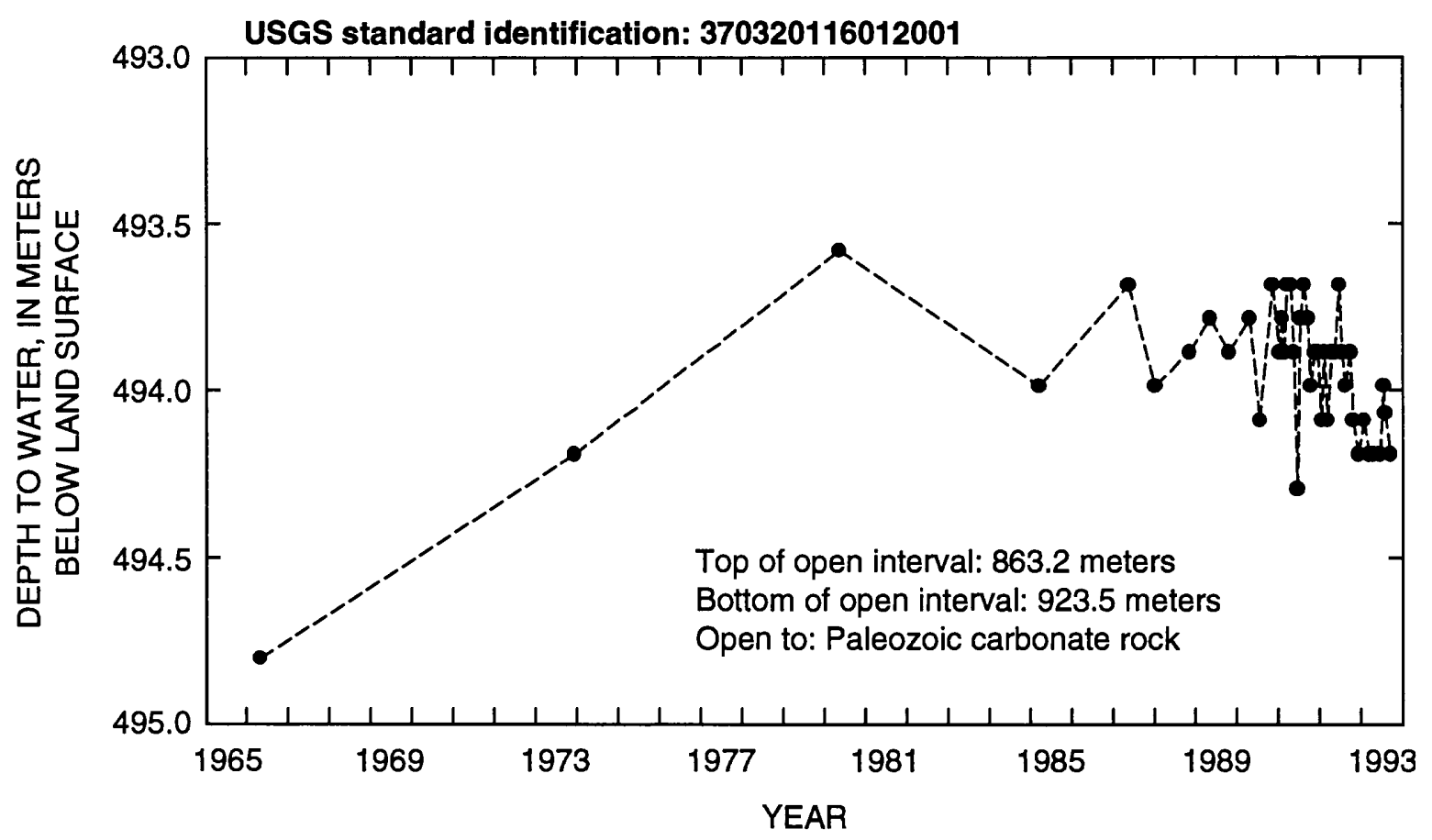

Flgure 4. Depth to water through water year 1993 in test hole U-3cn 5 in active testing area in Yucca Flat hydrcgraphic area (Area 3), Nevada Test Site. 


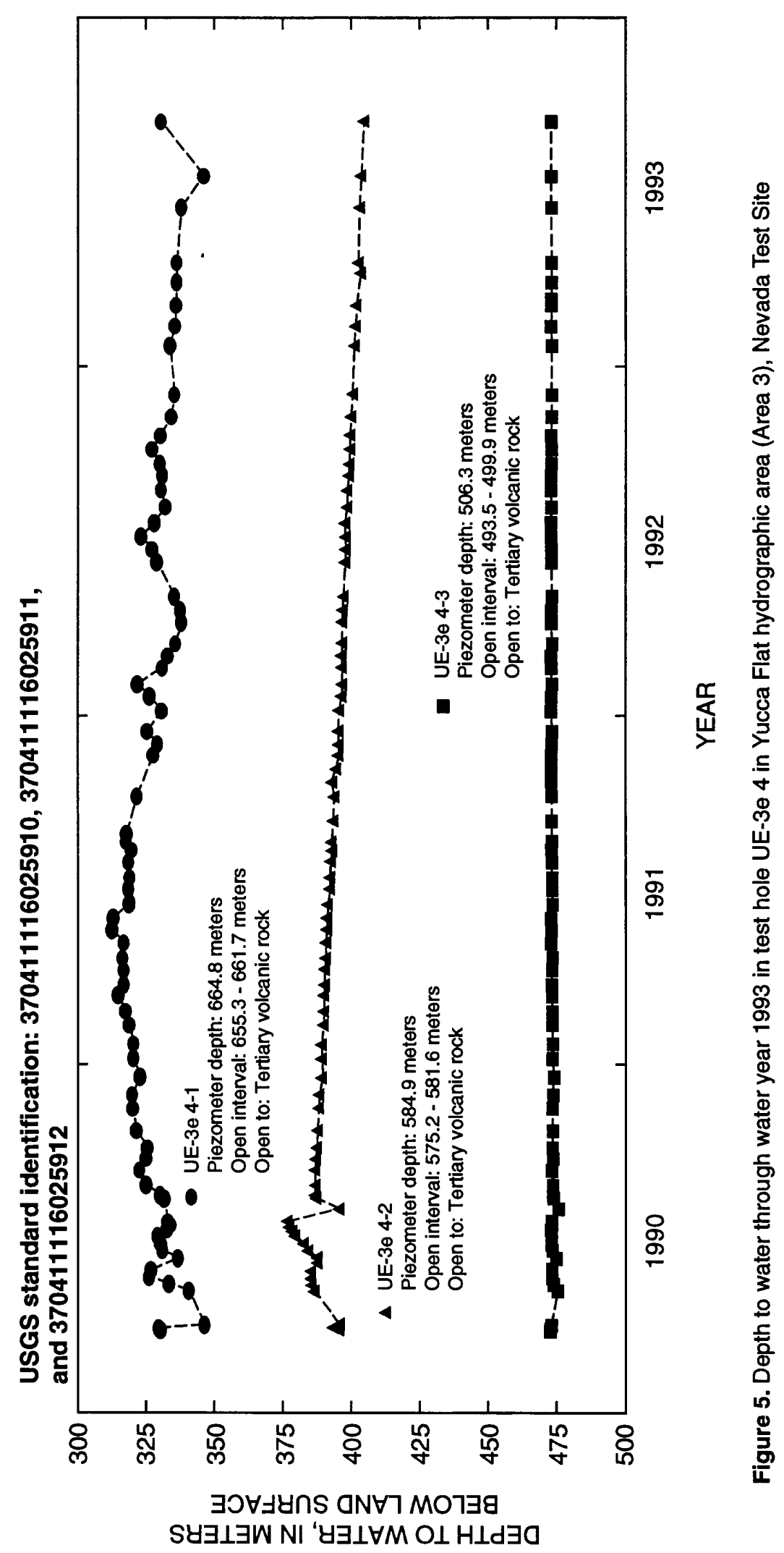

BASIC DATA 


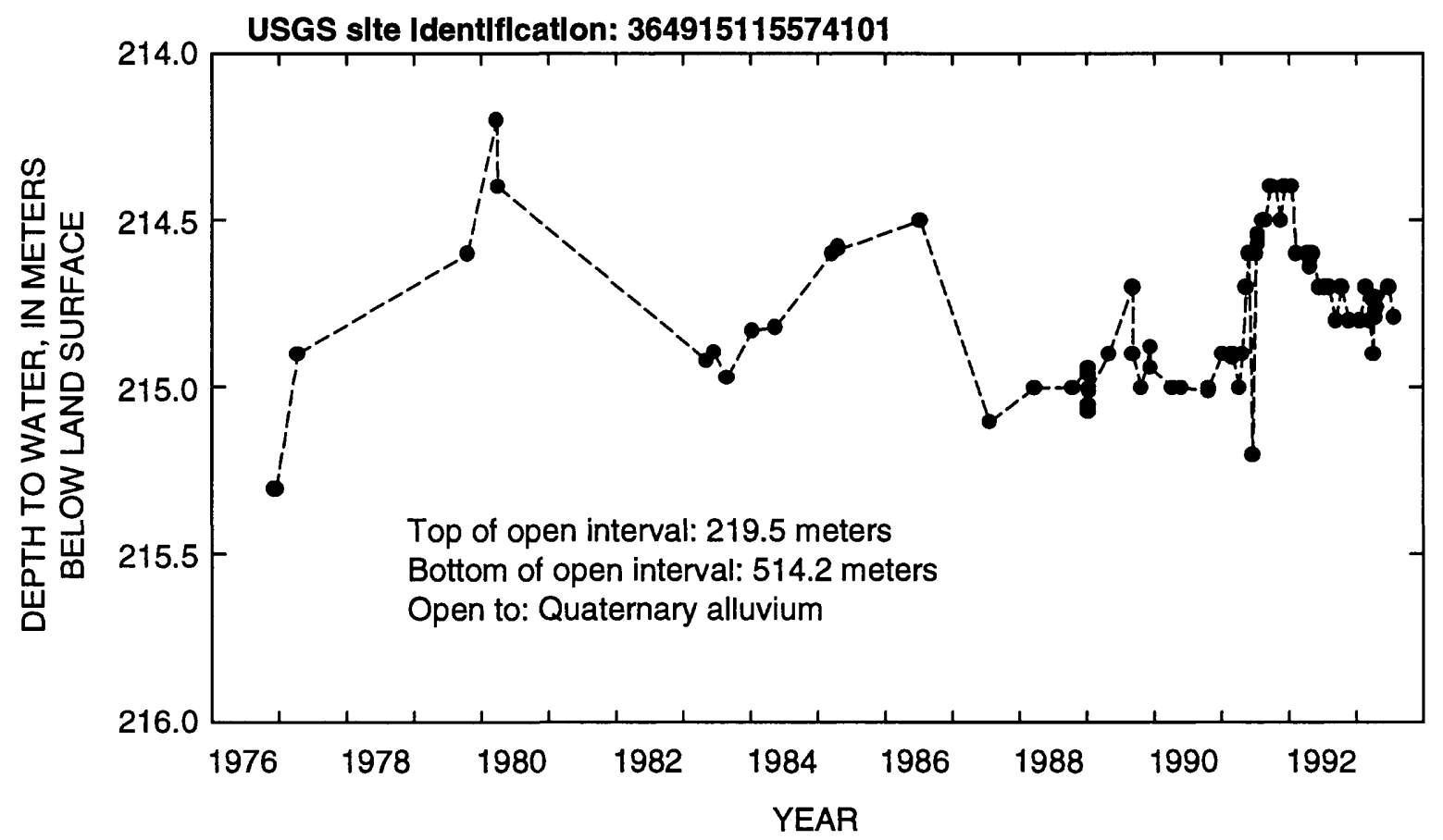

Figure 6. Depth to water through water year 1993 in test hole UE-5n in Frenchman Flat hydrographic area (Area 5), Nevada Test Site.

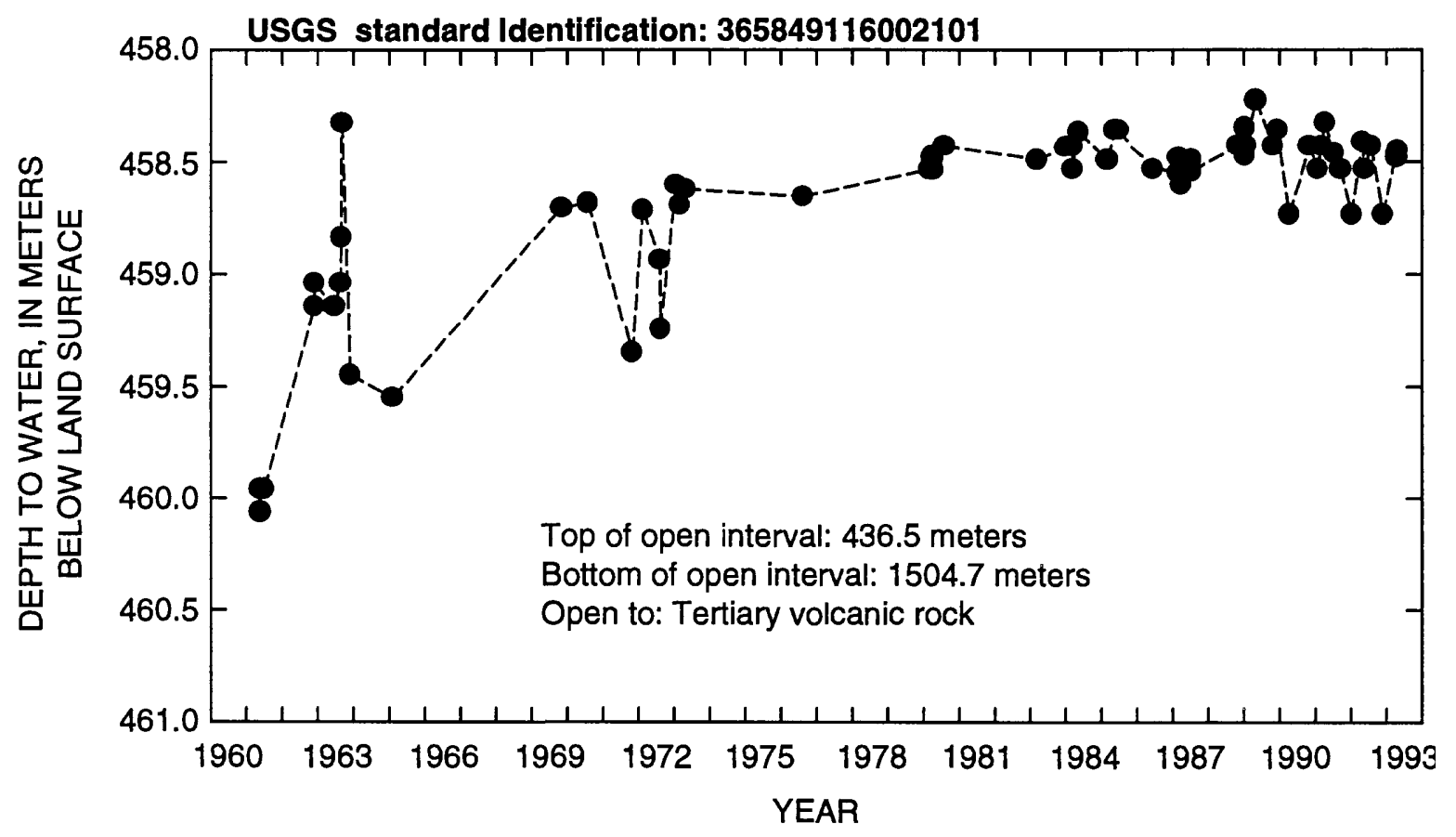

Figure 7. Depth to water through water year 1993 in well TW-B in Yucca Flat hydrographic area (Area 6), Nevada Test Site. 


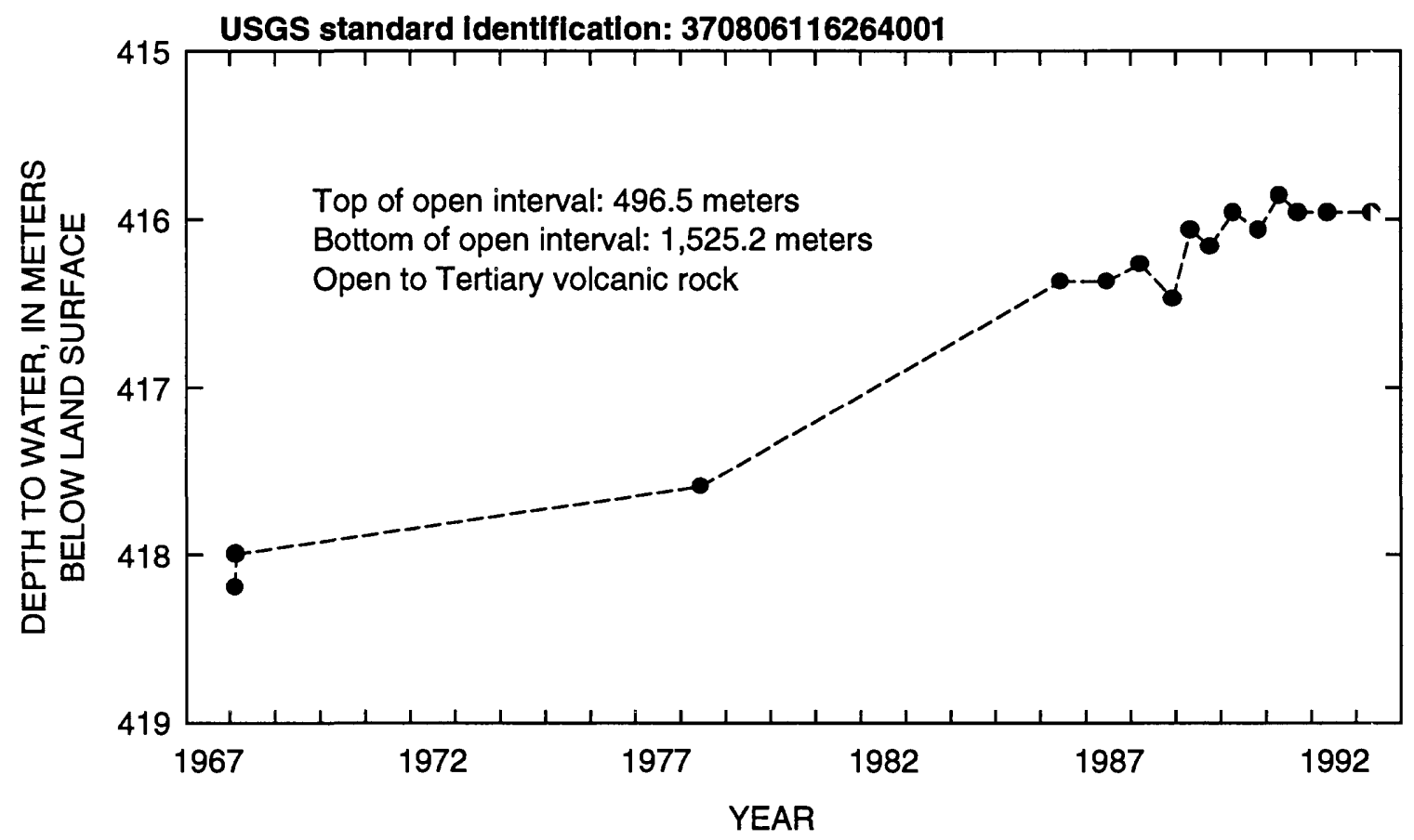

Figure 8. Depth to water through water year 1993 in test hole UE-18r on Buckboard Mesa (Area 18), Nevada Test Site.

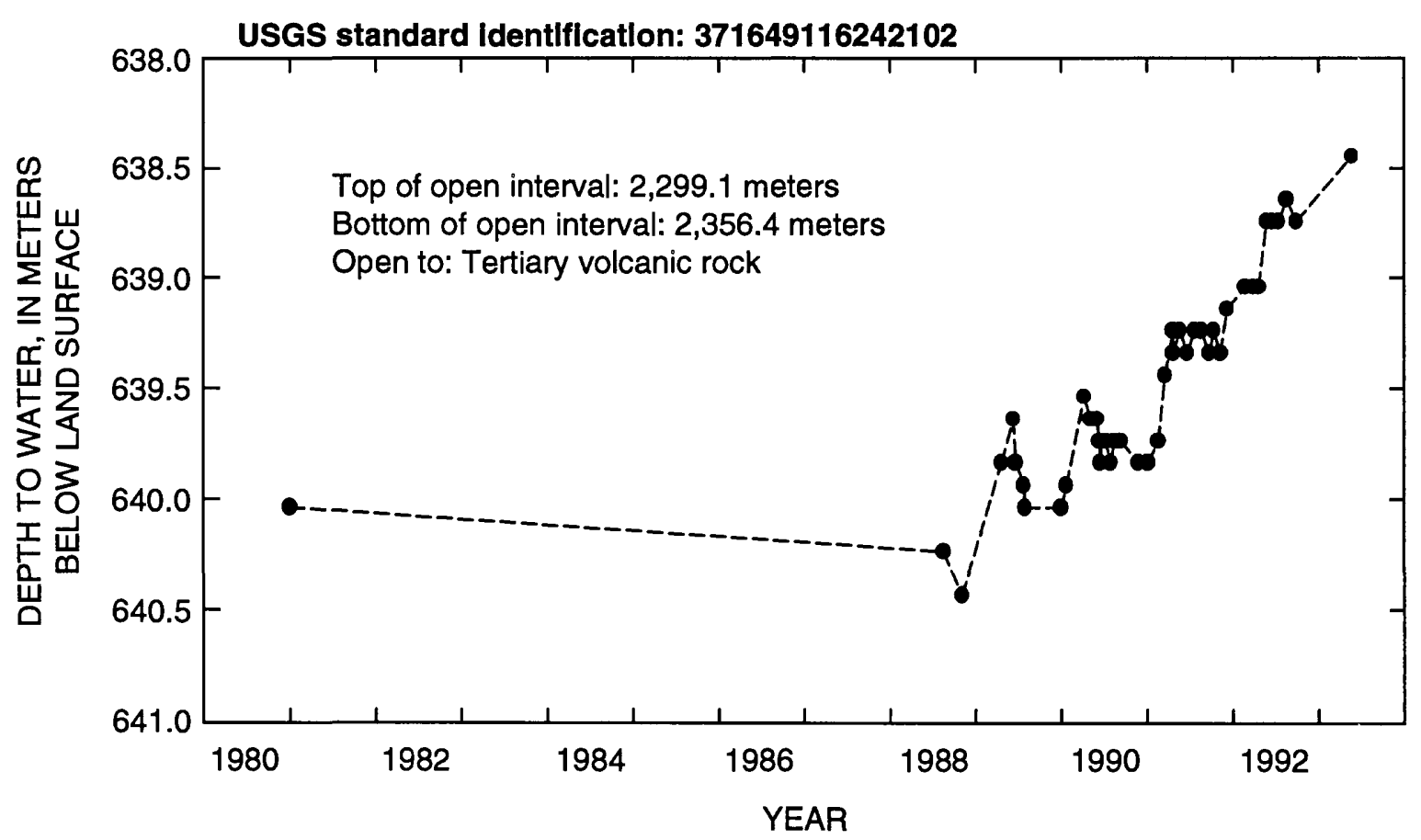

Figure 9. Depth to water through water year 1993 in test hole PM-1 on Pahute Mesa (Area 20), Nevada Te-t Slte 


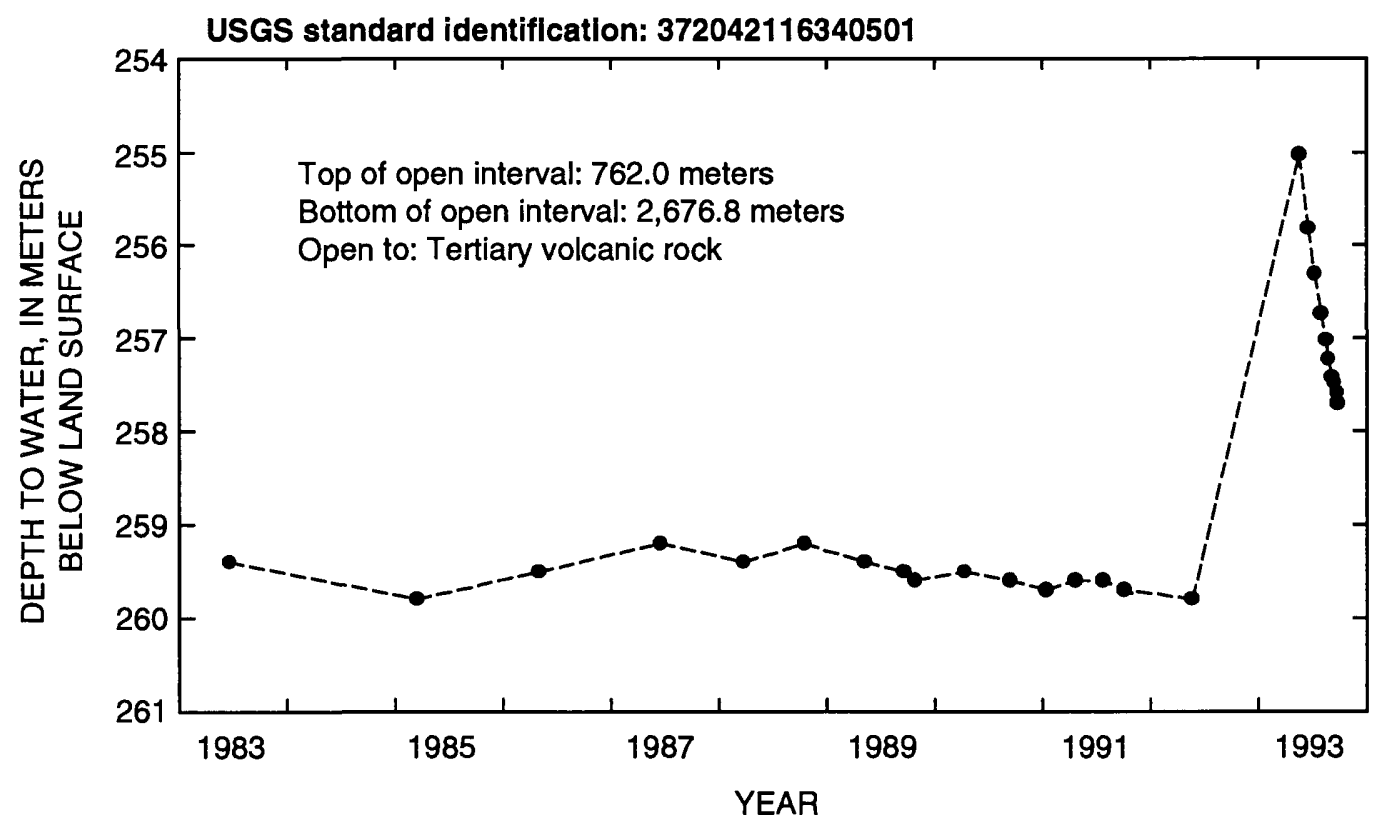

Figure 10. Depth to water through water year 1993 in test hole PM-2 on Pahute Mesa (Area 20), Nevada Test Site.

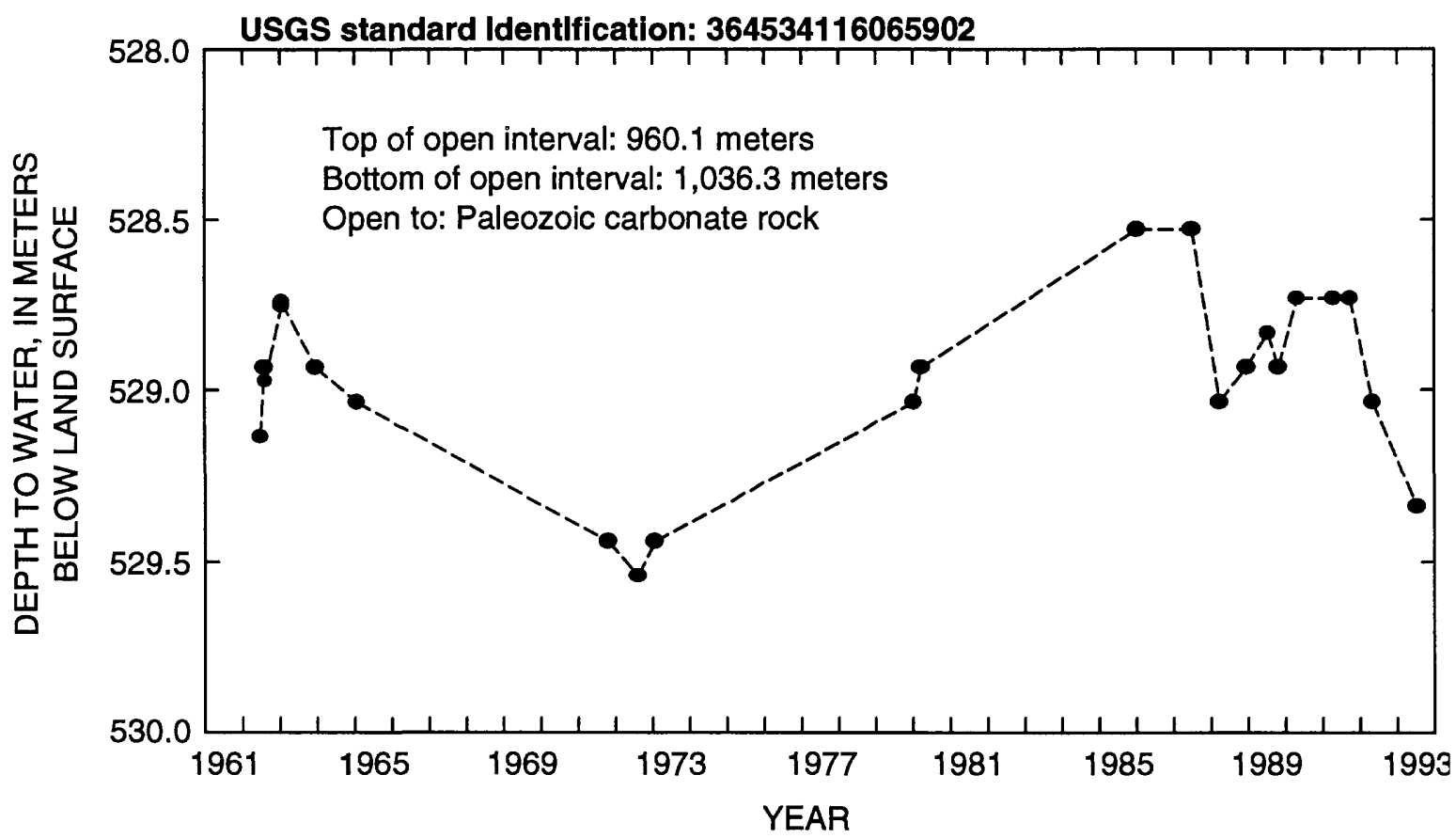

Figure 11. Depth to water through water year 1993 in well TW-F in Frenchman Flat hydrographic area (Area 27), Nevada Test Site. 


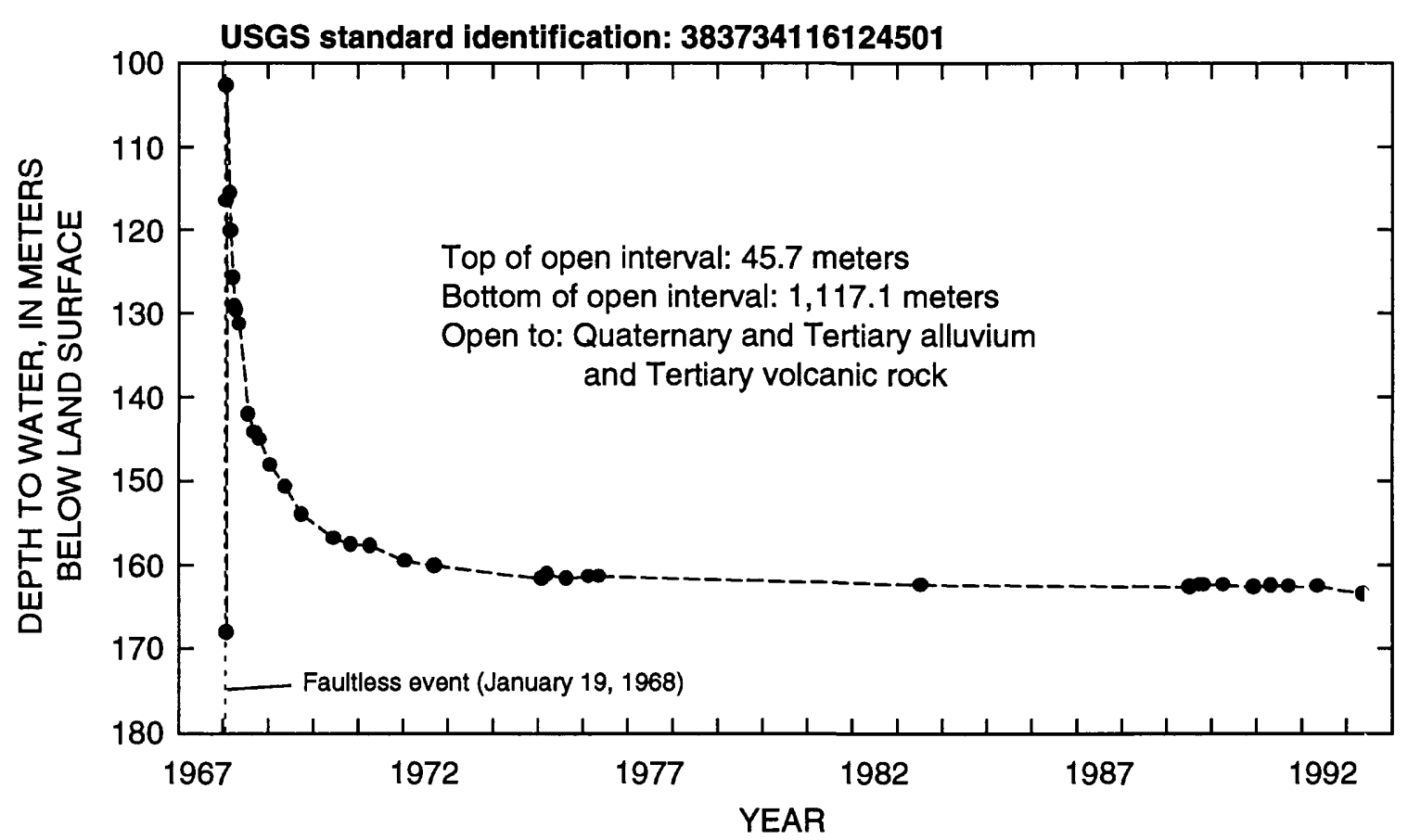

Figure 12. Depth to water through water year 1993 in test hole HTH-1 in Hot Creek Valley hydrographic area in vicinity of Nevada Test Site. Name and date are indicated for nearby weapon test.

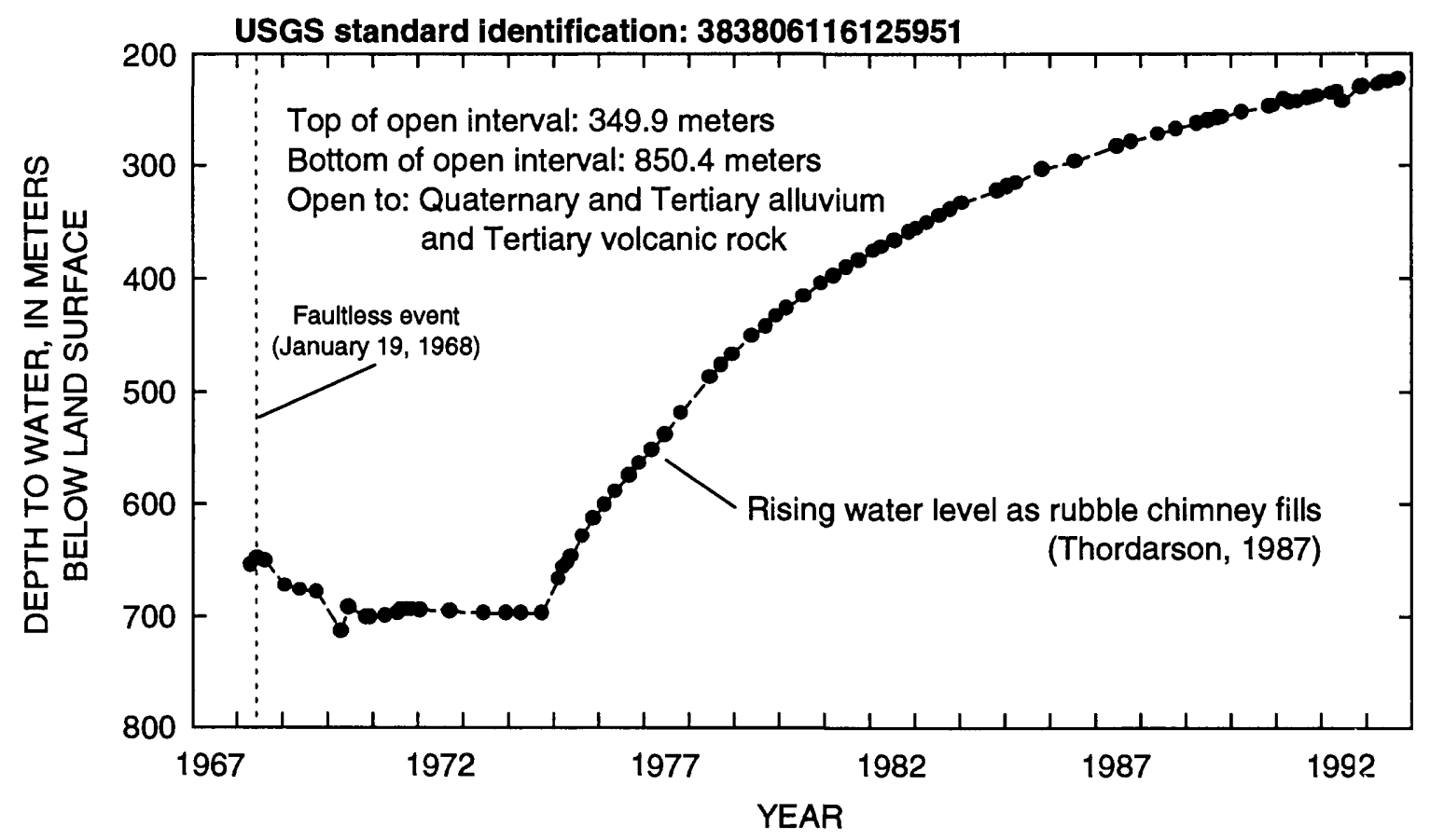

Flgure 13. Depth to water through water year 1993 in test hole UC-1-P-2SR in Hot Creek Valley hydrographic area in vicinity of Nevada Test Site. Name and date are indicated for nearby weapon test. 


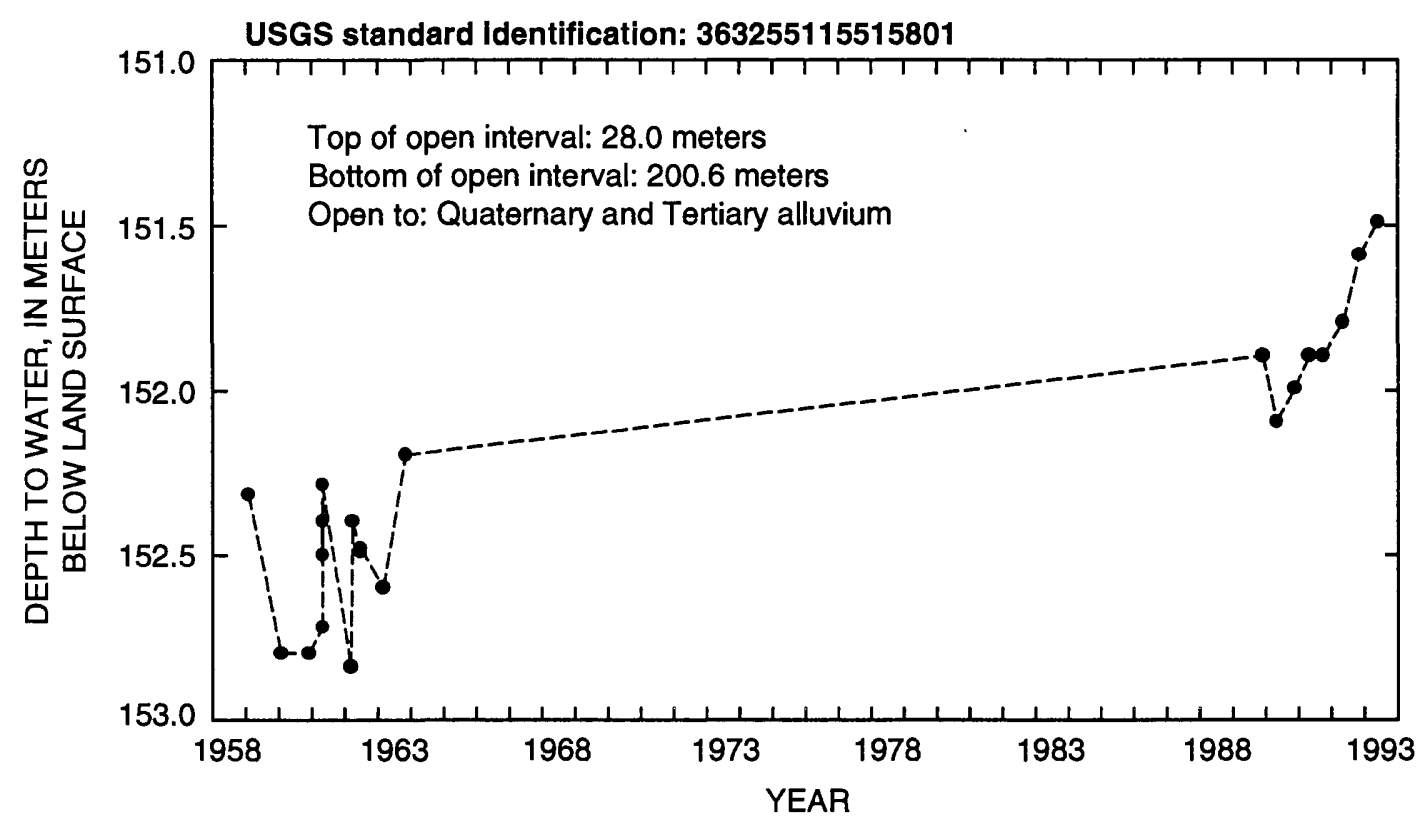

Figure 14. Depth to water through water year 1993 in well Army 2 in Indian Springs Valley hydrographic area in vicinity of Nevada Test Site.

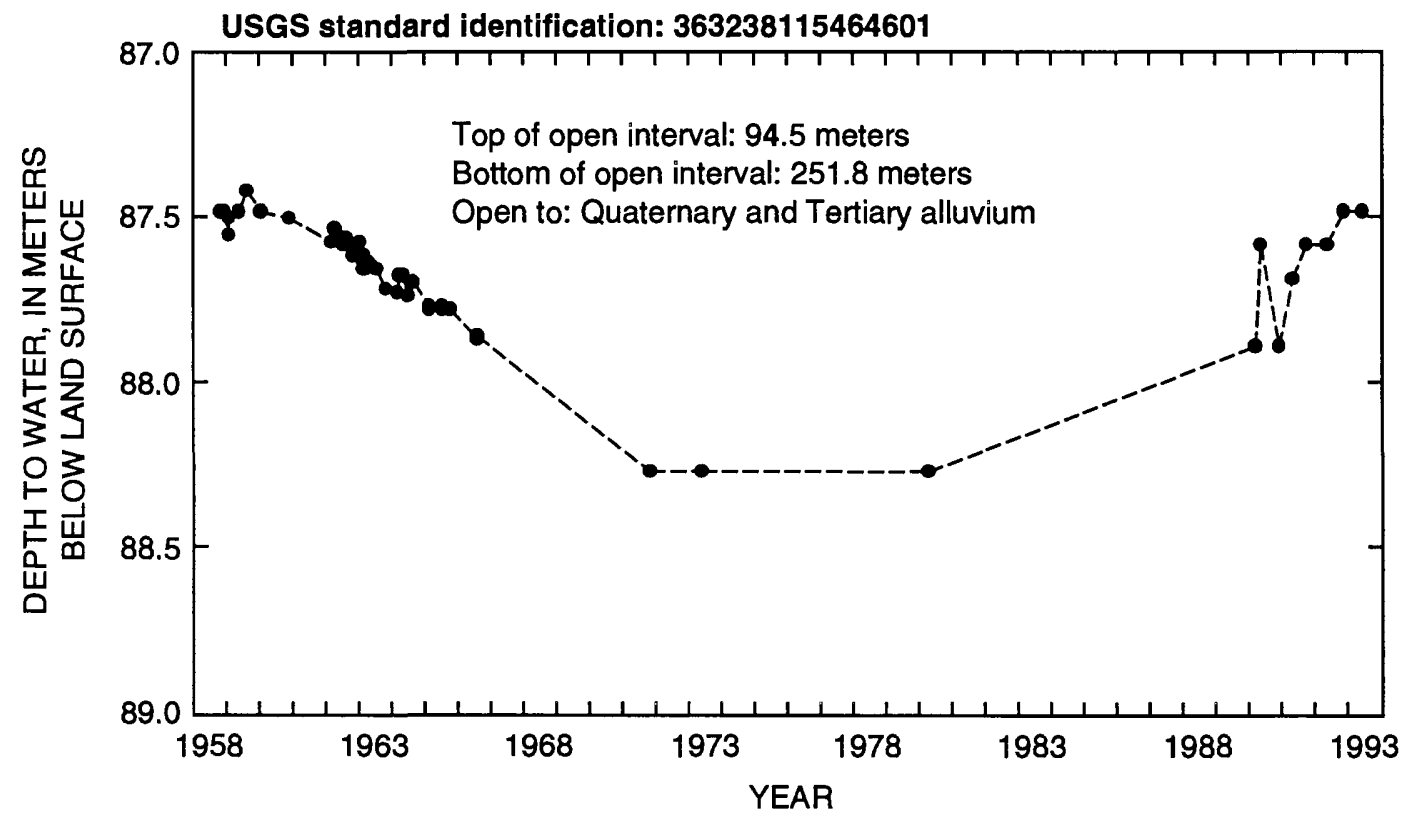

Figure 15. Depth to water through water year 1993 in well Army 3 in Indian Springs Valley hydrographic area in vicinity of Nevada Test Site. 


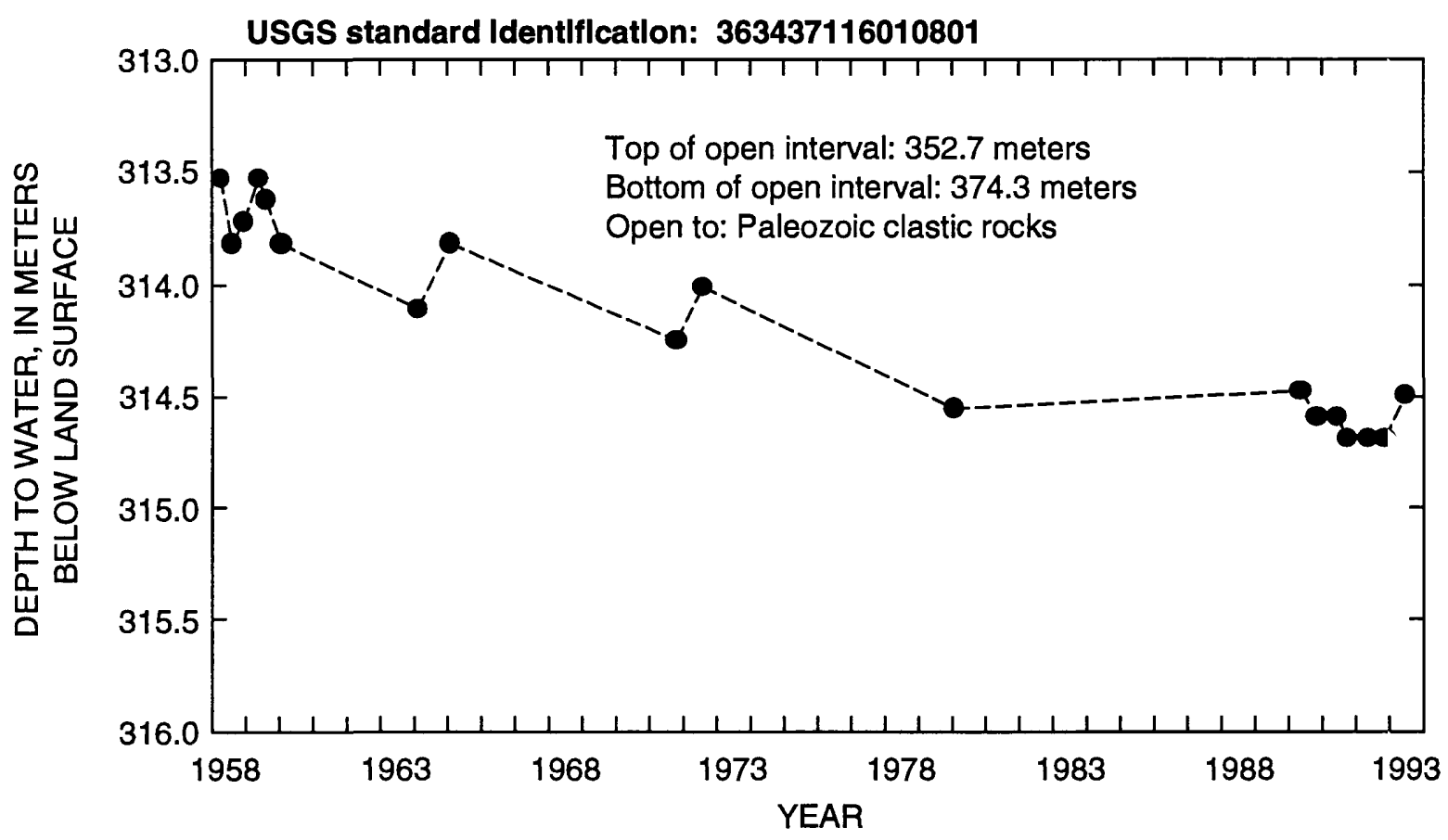

Figure 16. Depth to water through water year 1993 in well Army 6A in Mercury Valley hydrographic area in vicinity of Nevada Test Site.

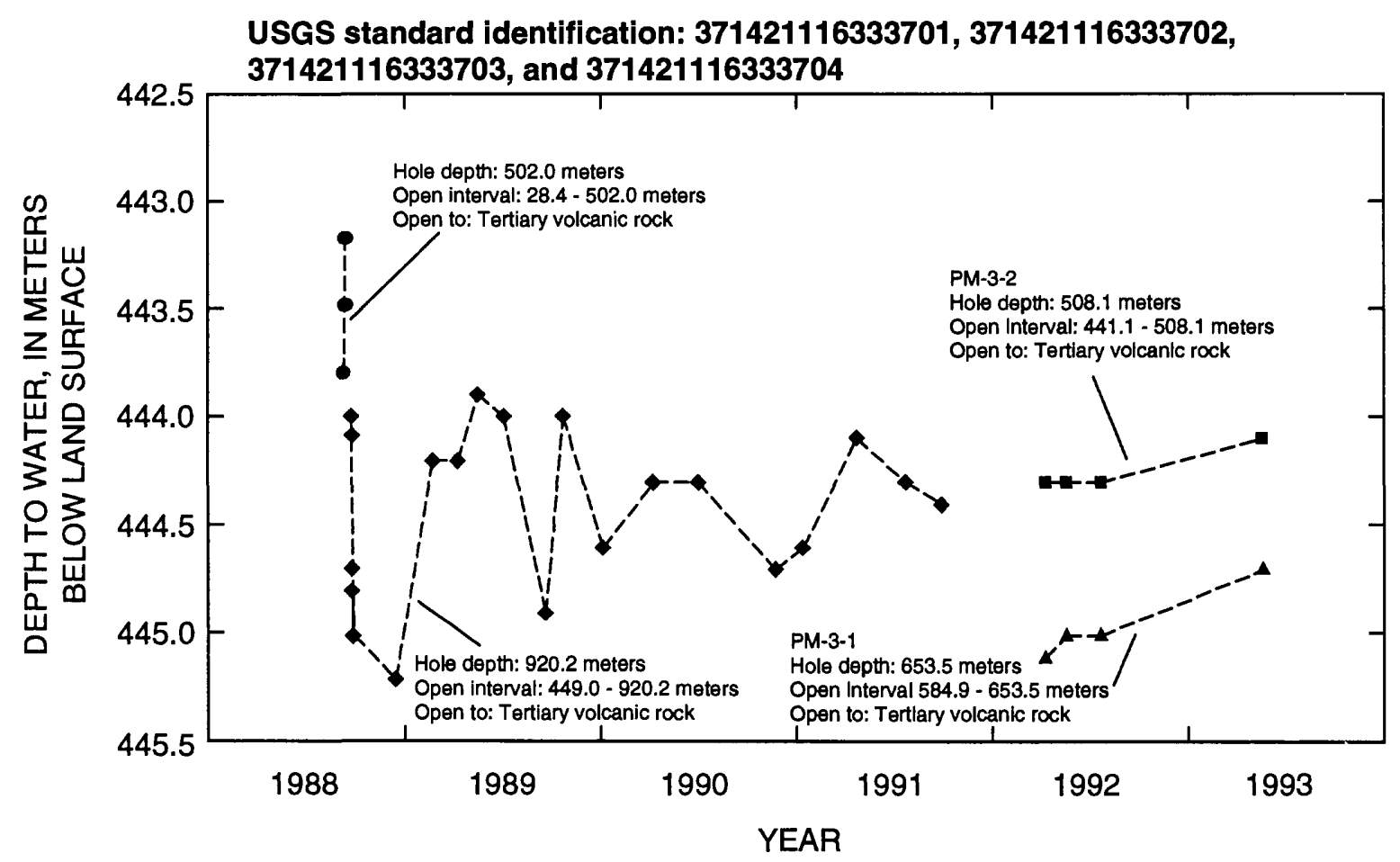

Figure 17. Depth to water through water year 1993 in test hole PM-3 in Oasis Valley hydrographic area in vicinity of Nevada Test Site. 


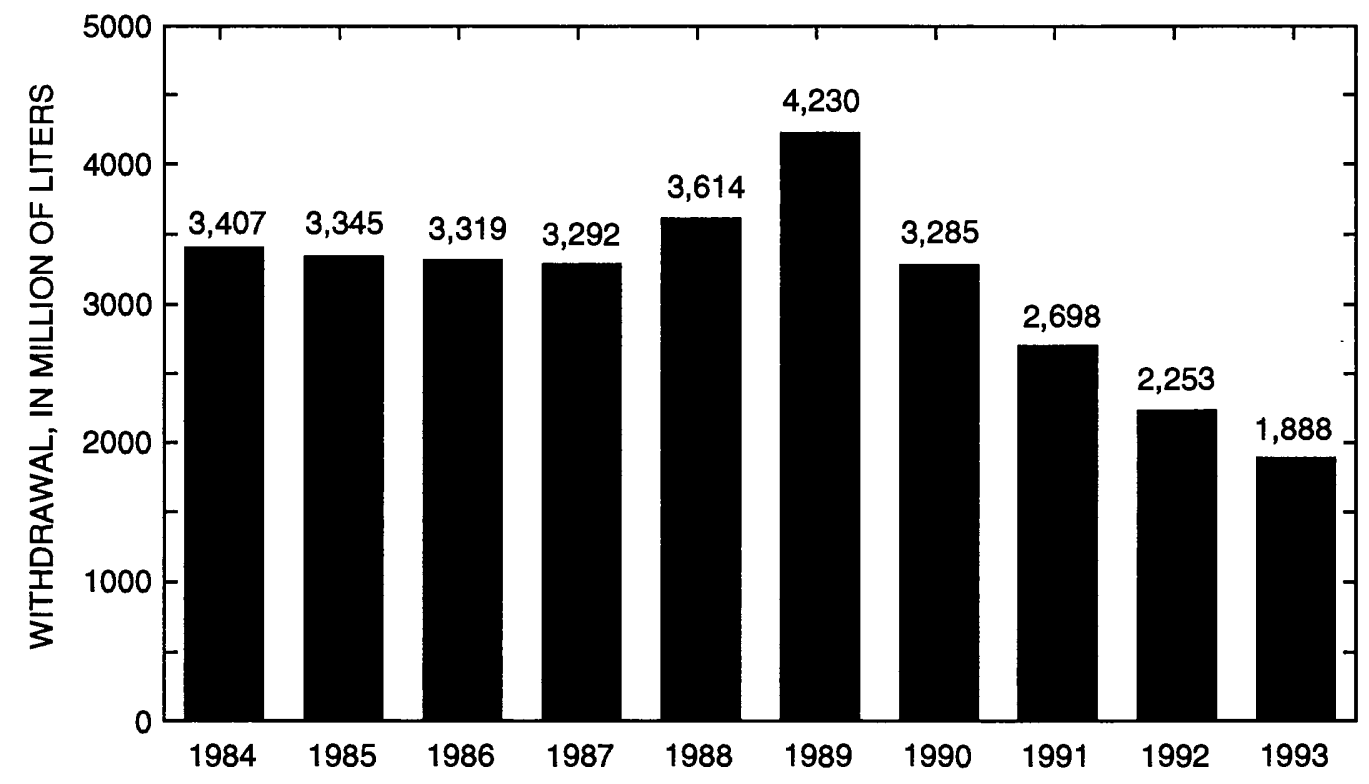

Figure 18. Annual ground-water withdrawals from Nevada Test Site, 1984-93.

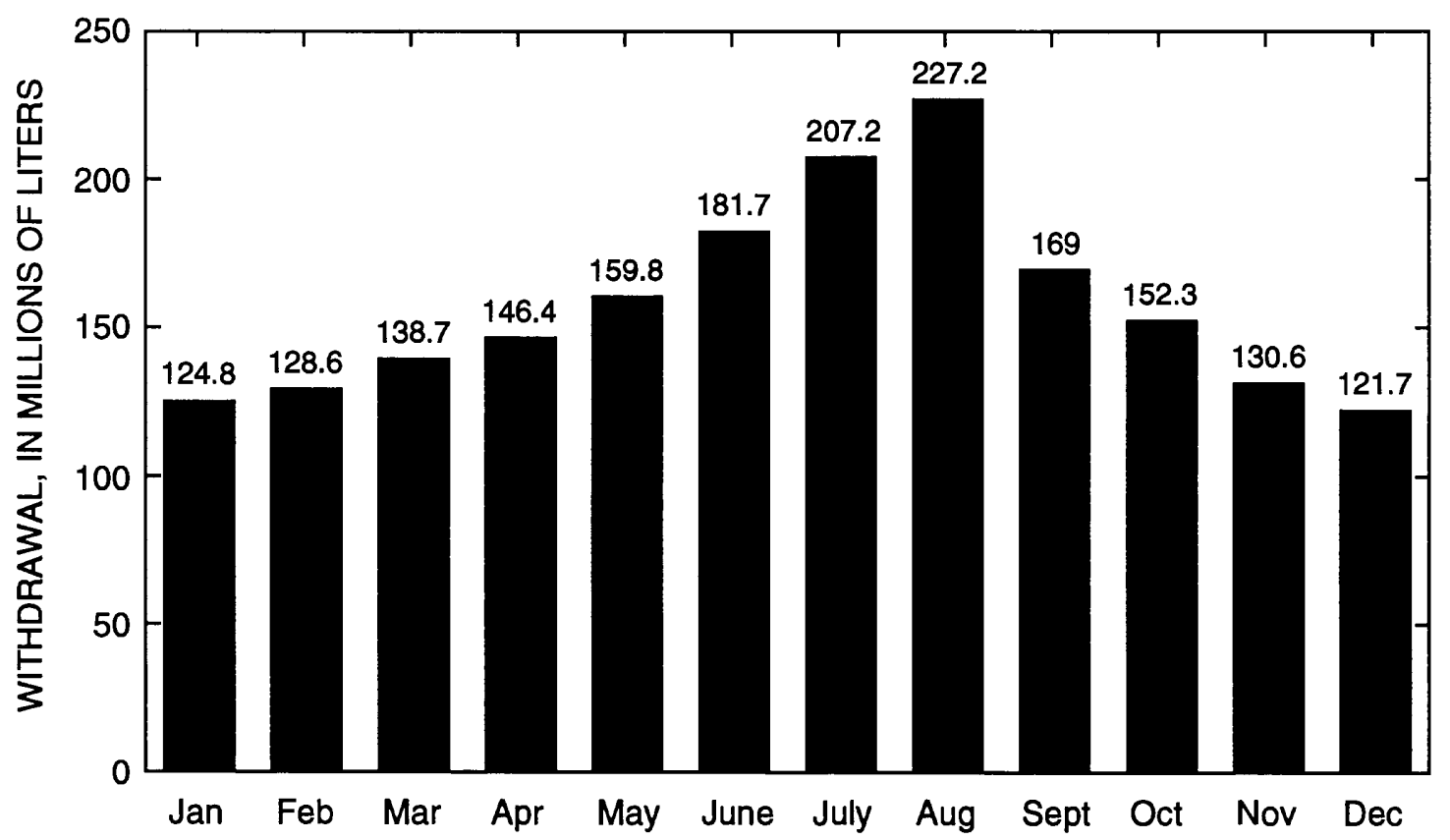

Figure 19. Monthly ground-water withdrawals from Nevada Test Site, 1993. 


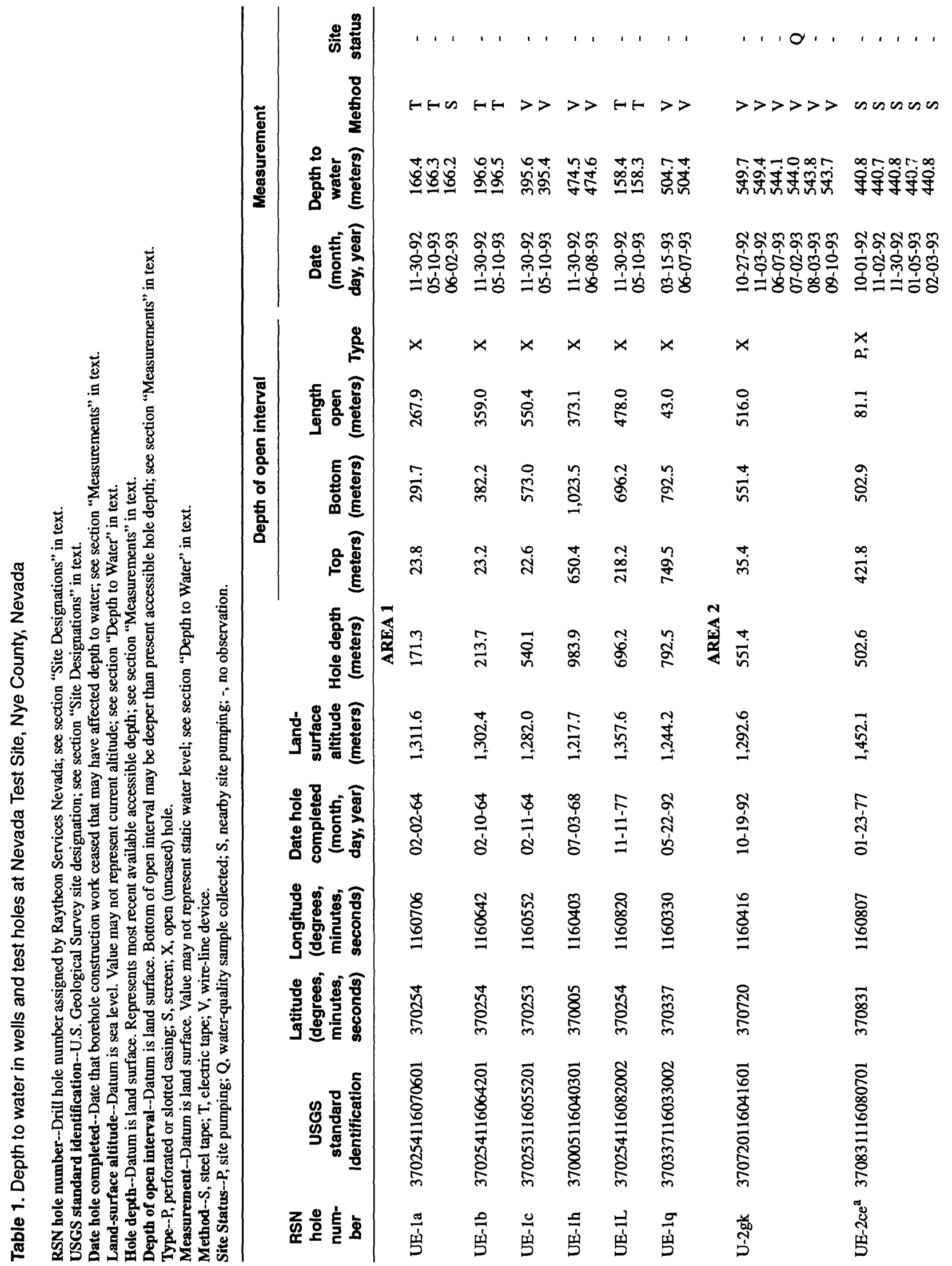




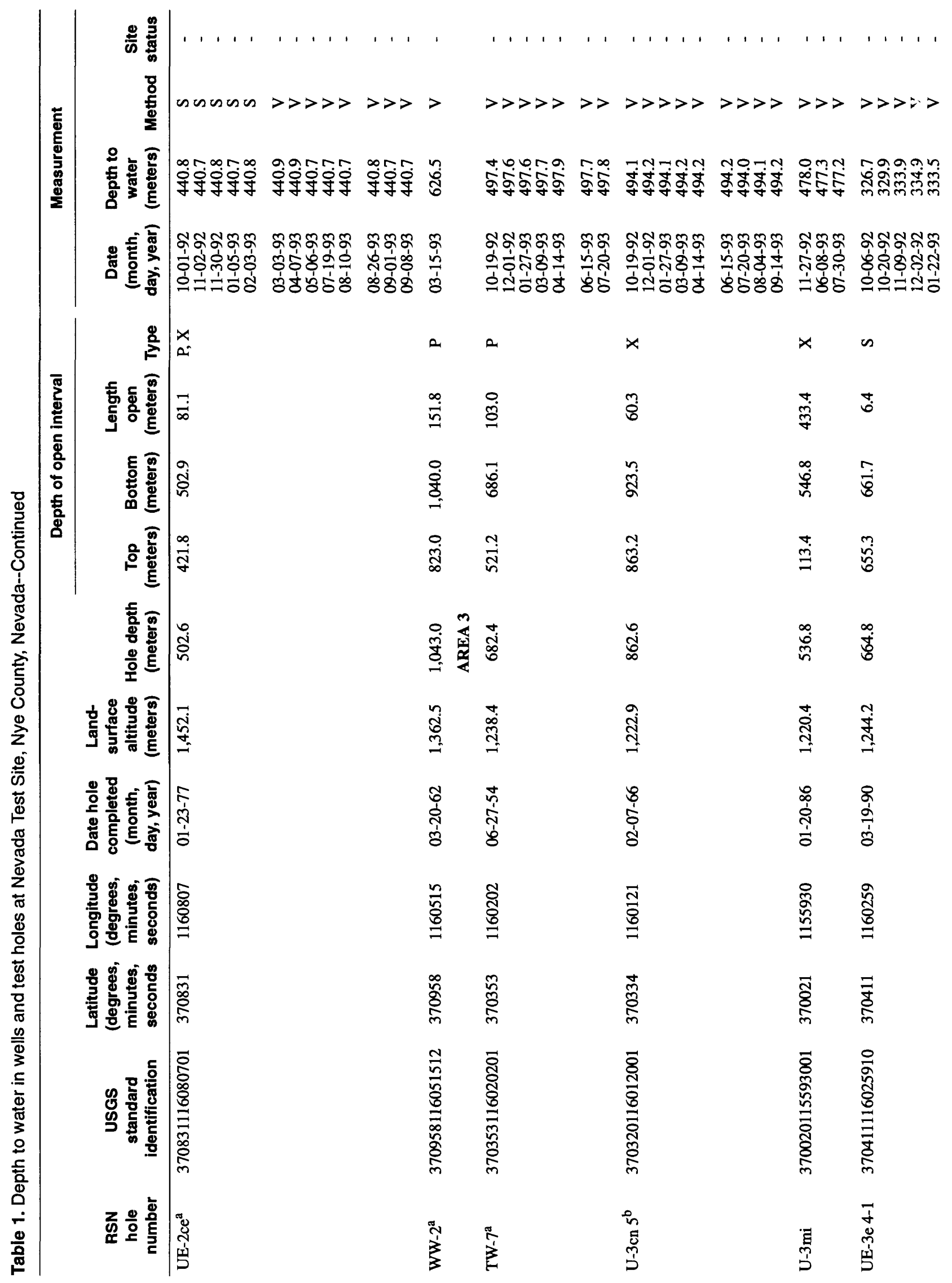




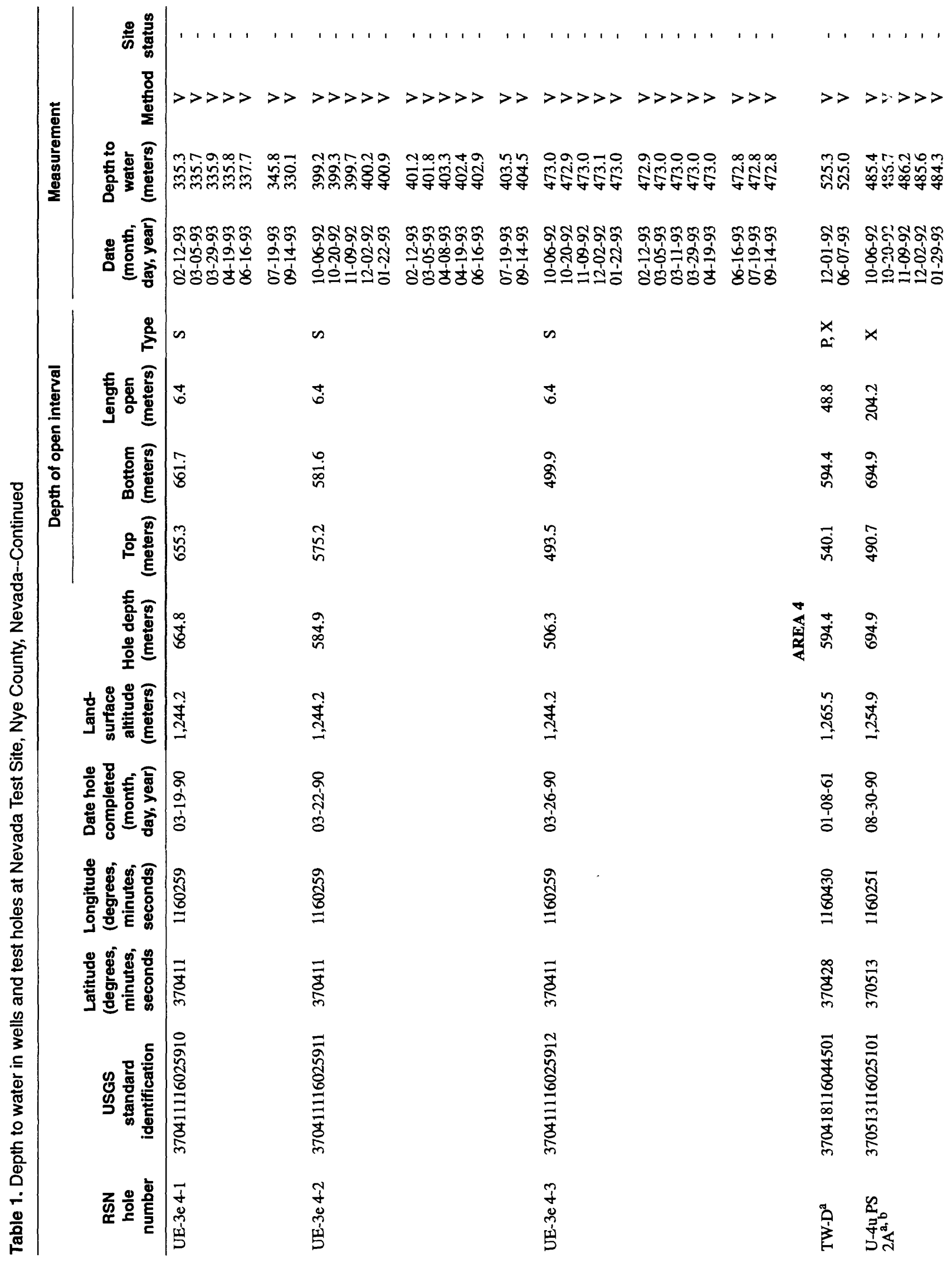




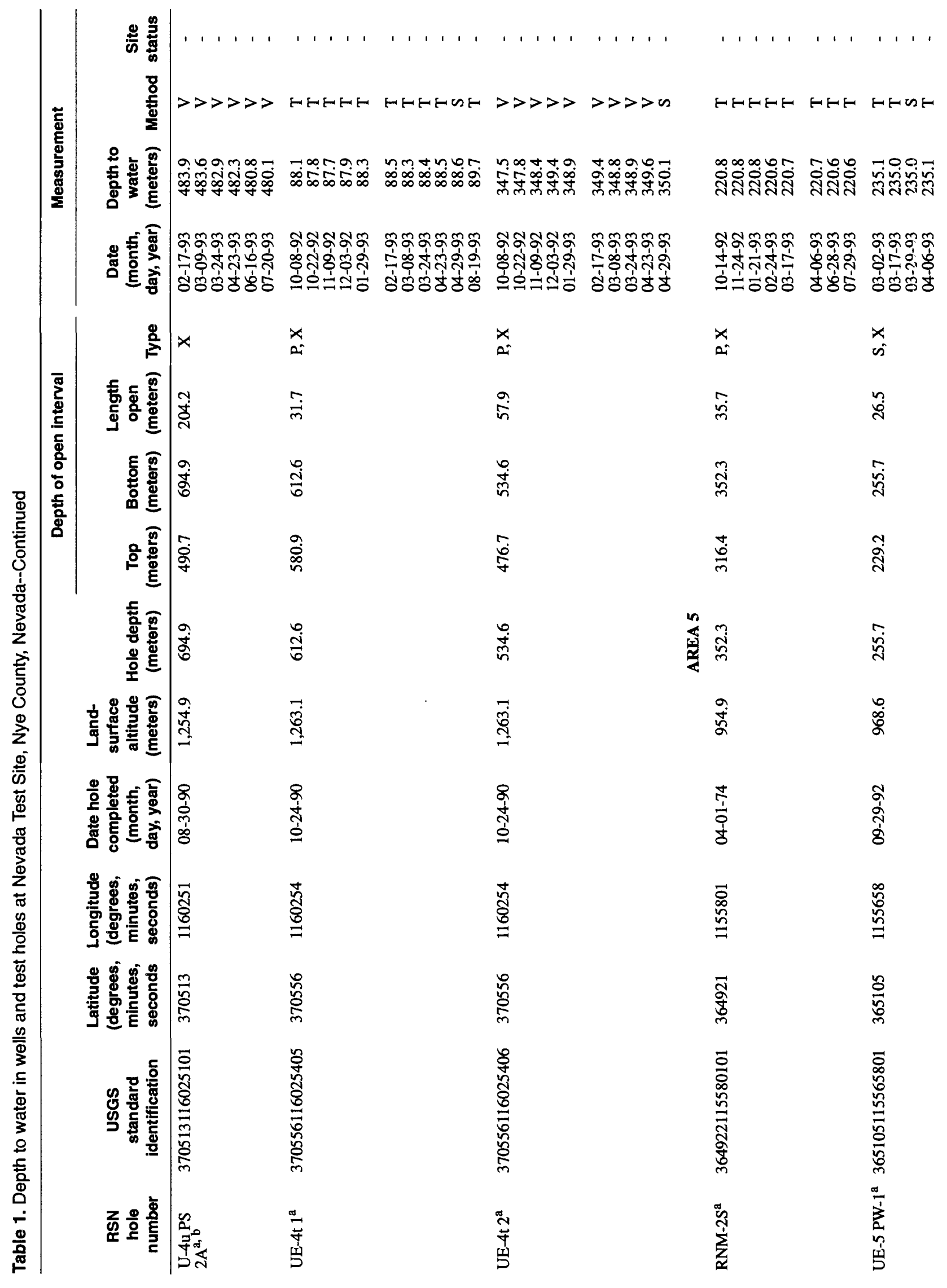




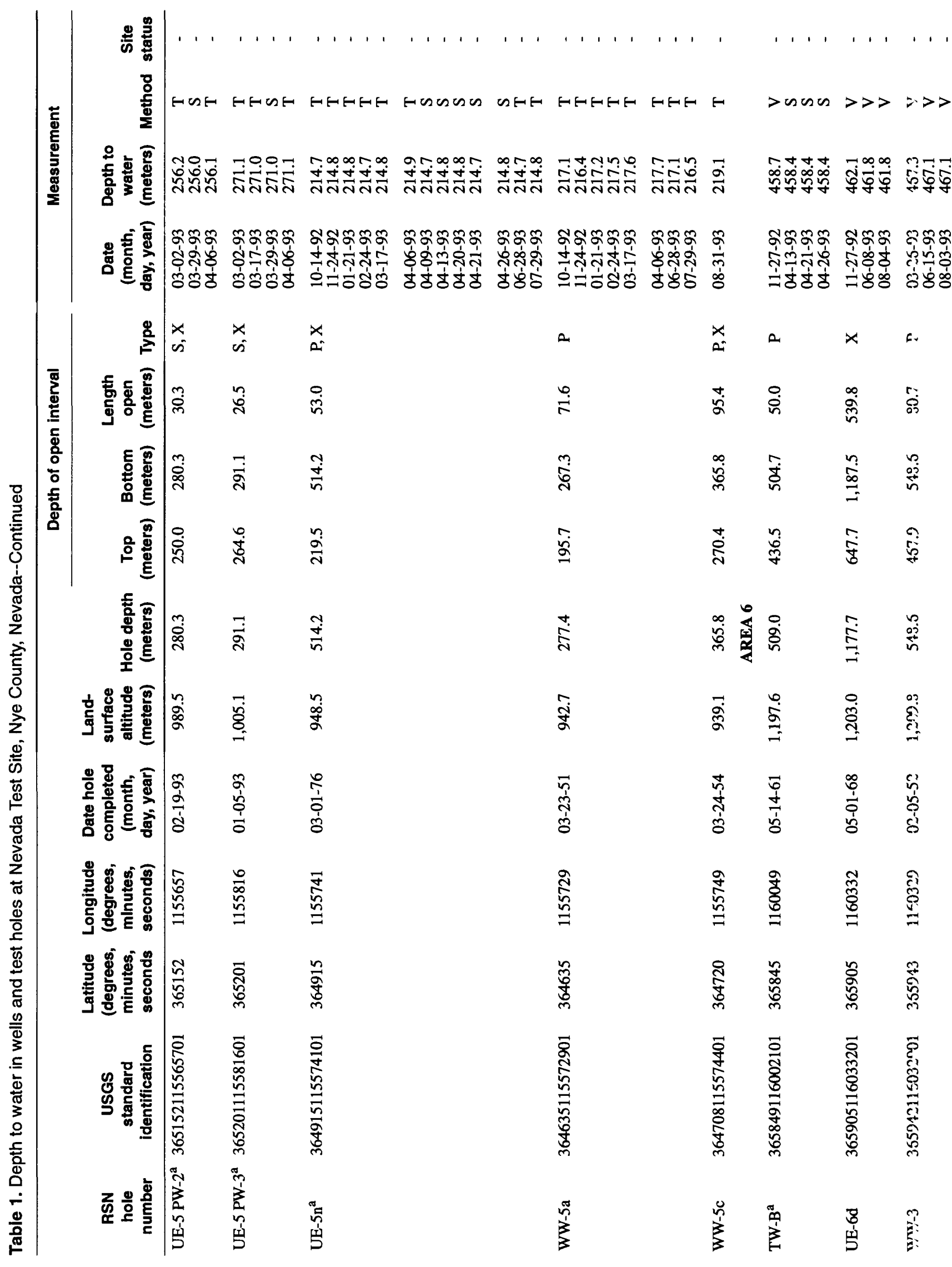




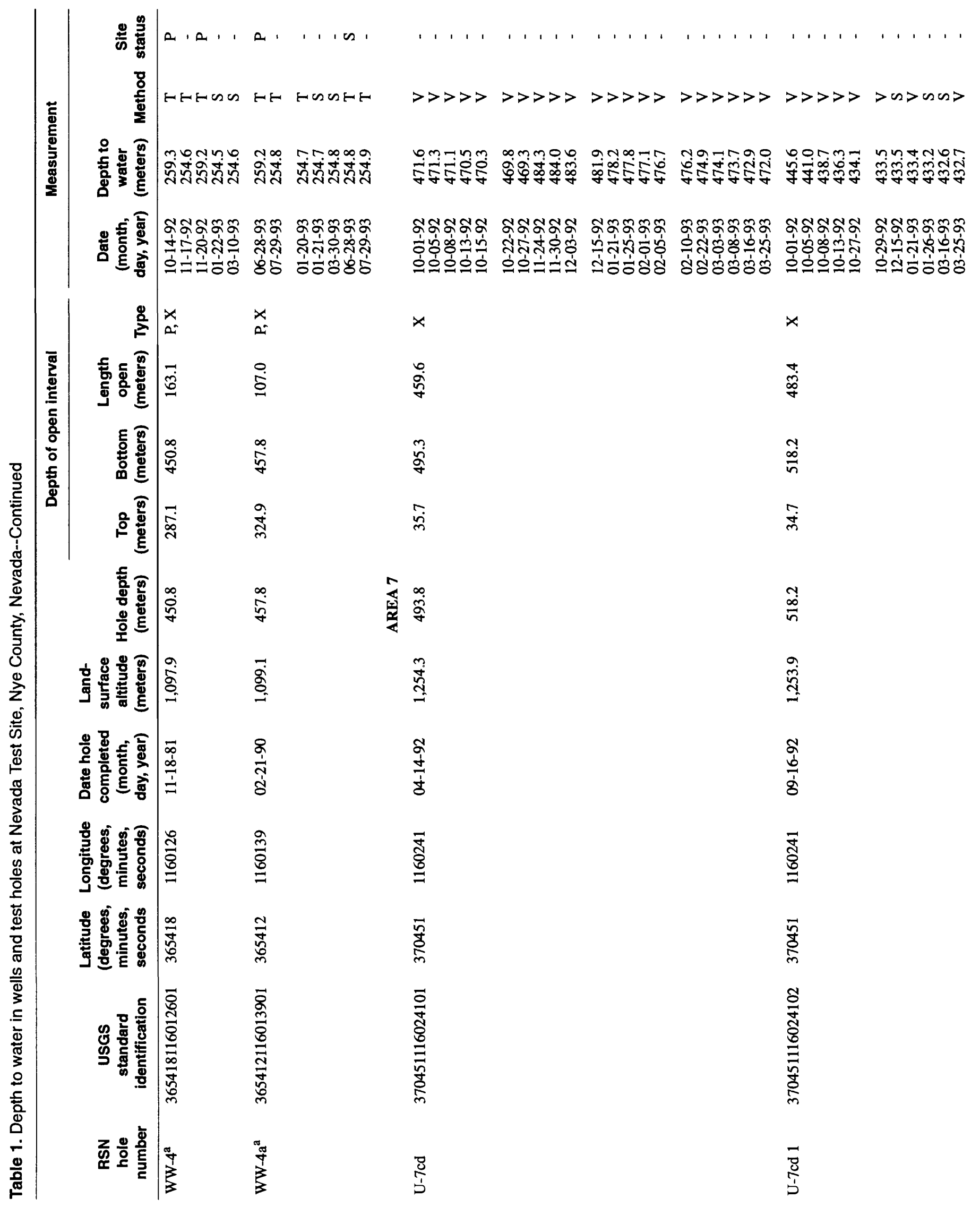




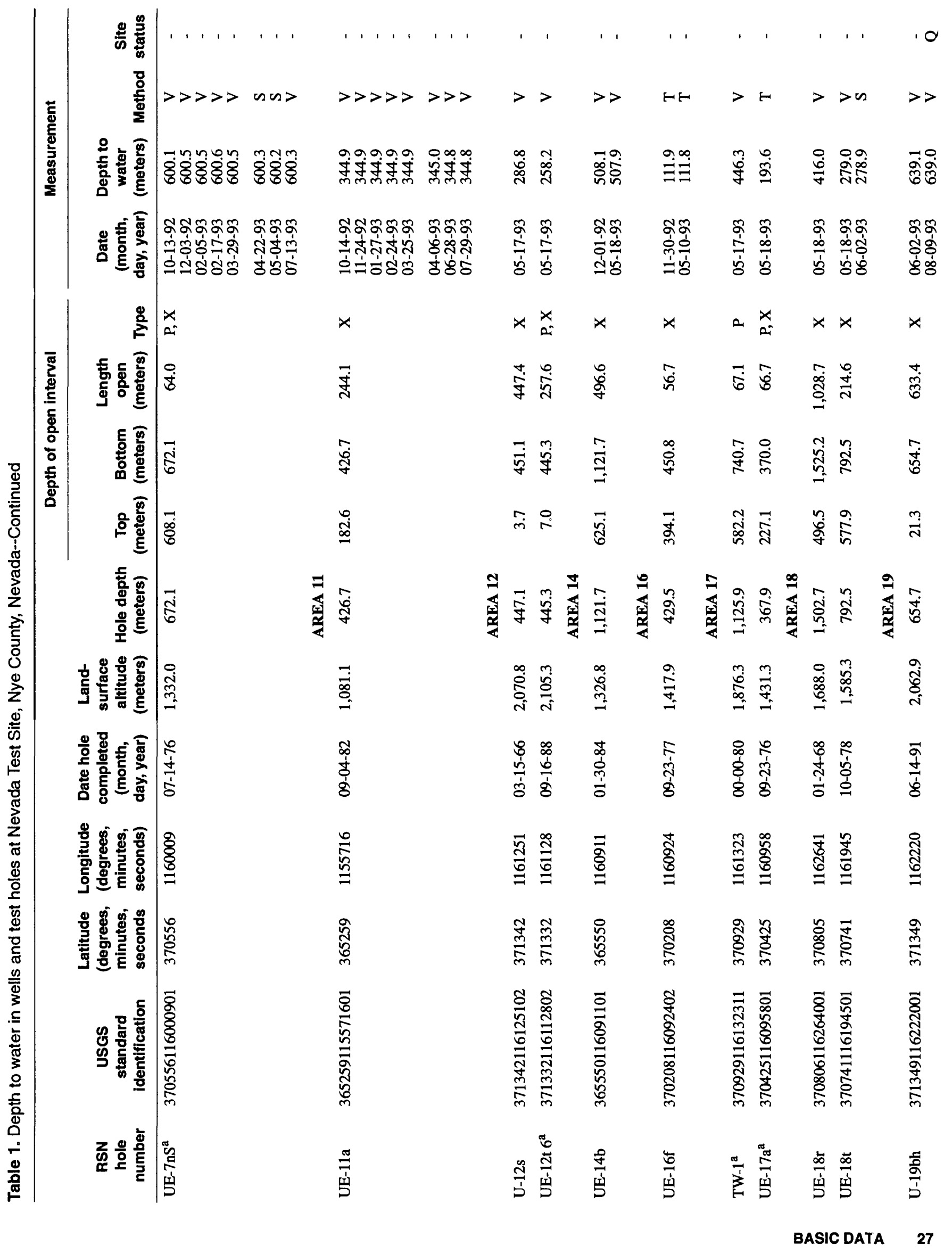




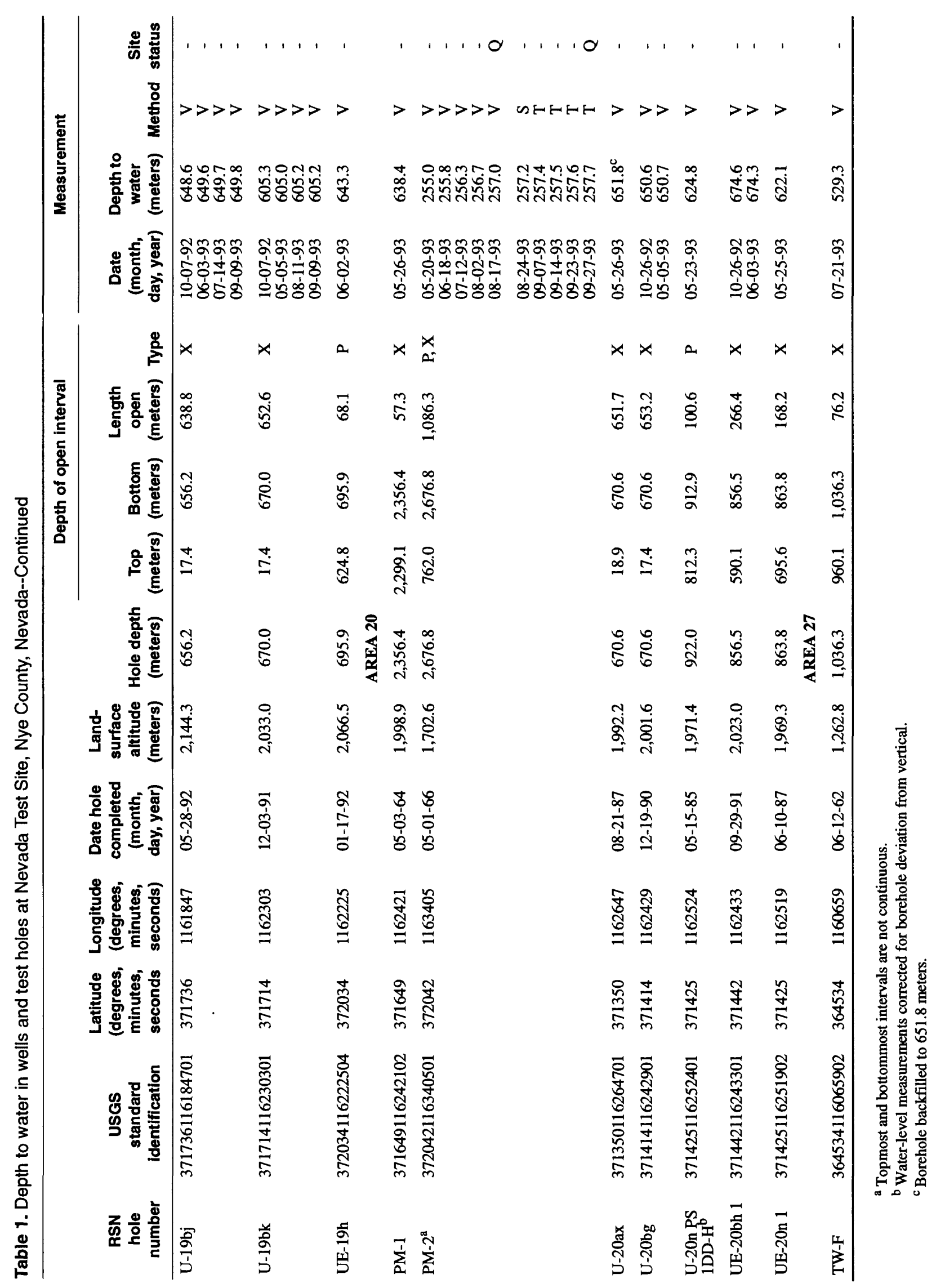




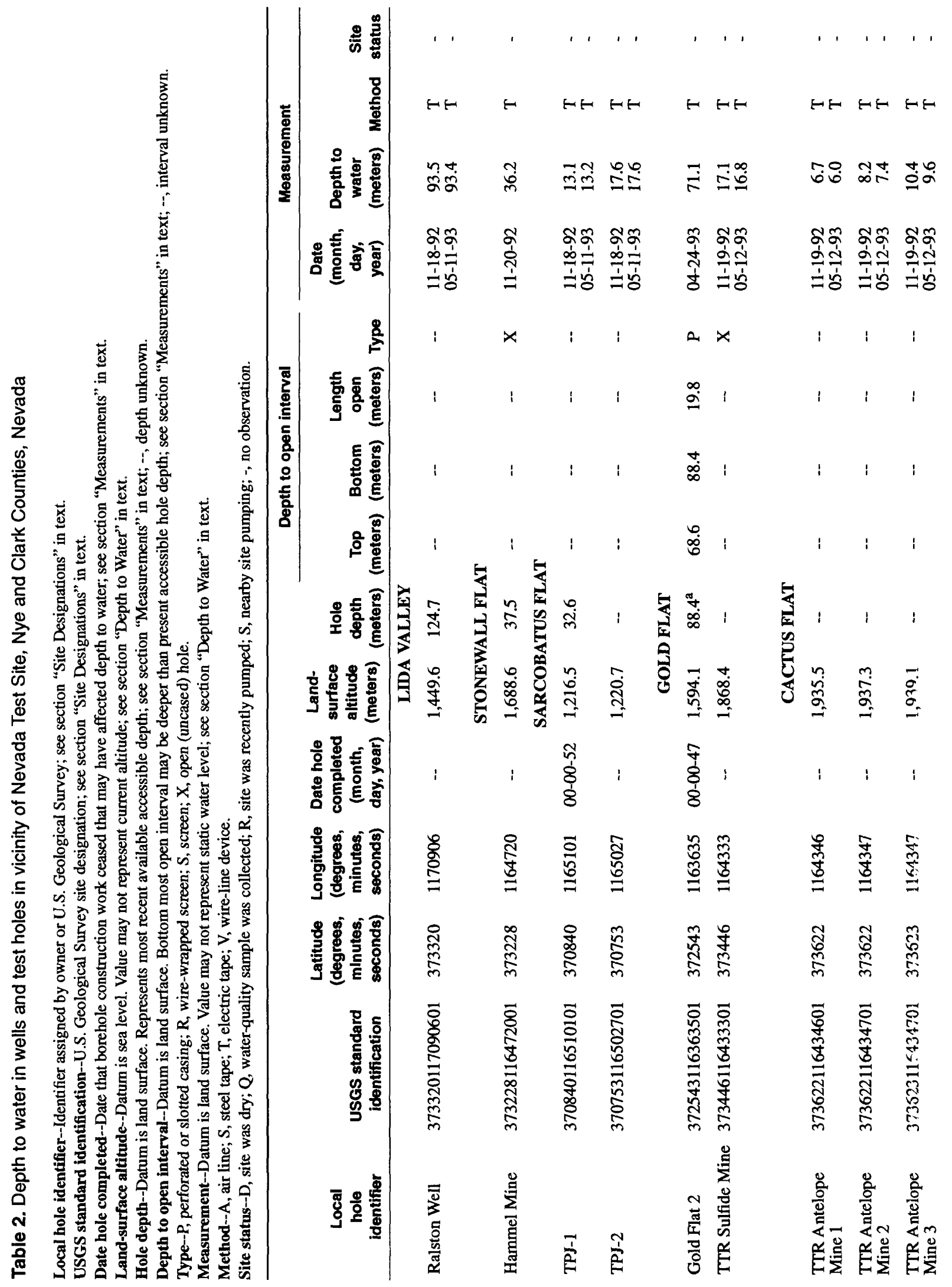




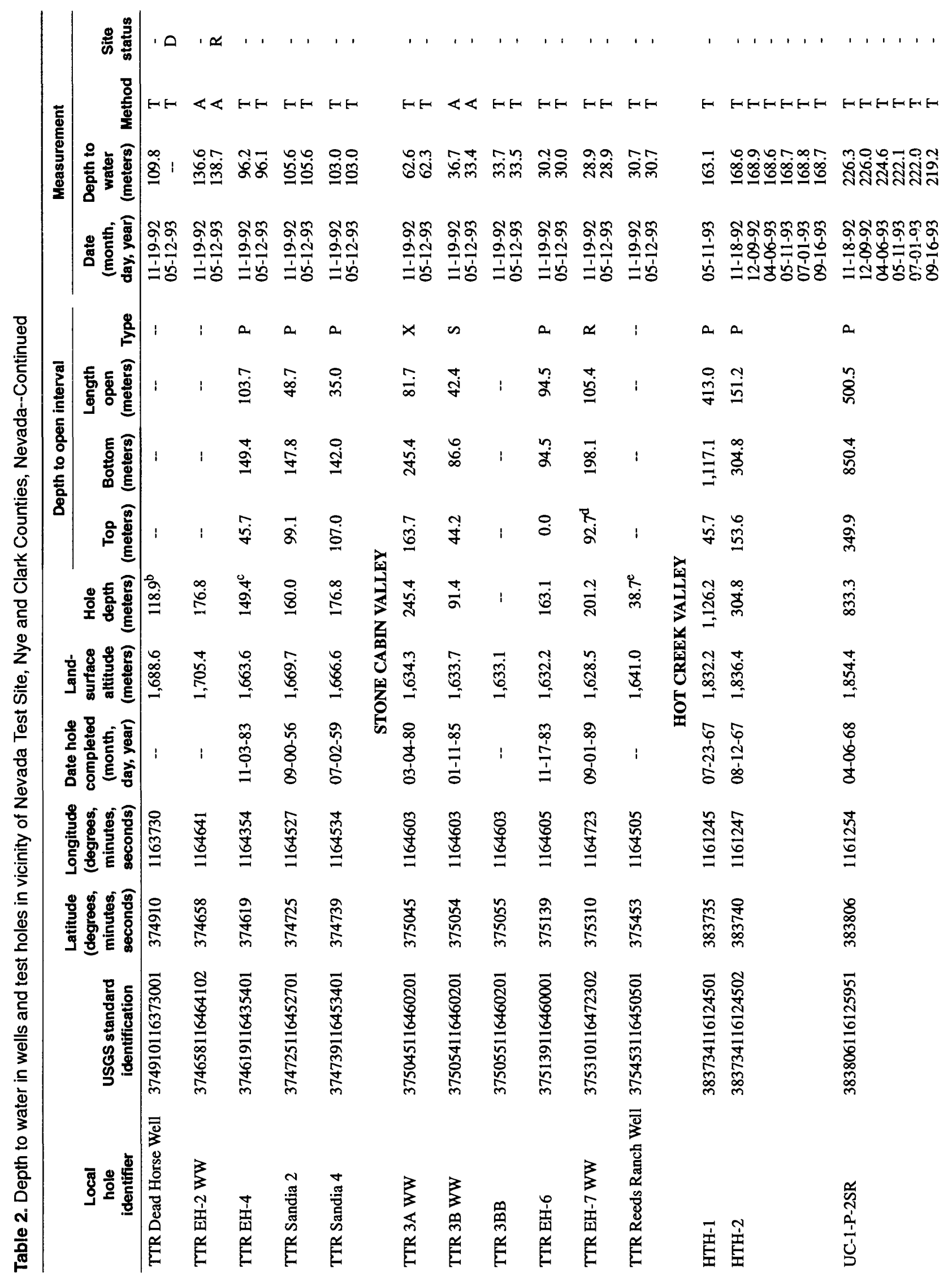




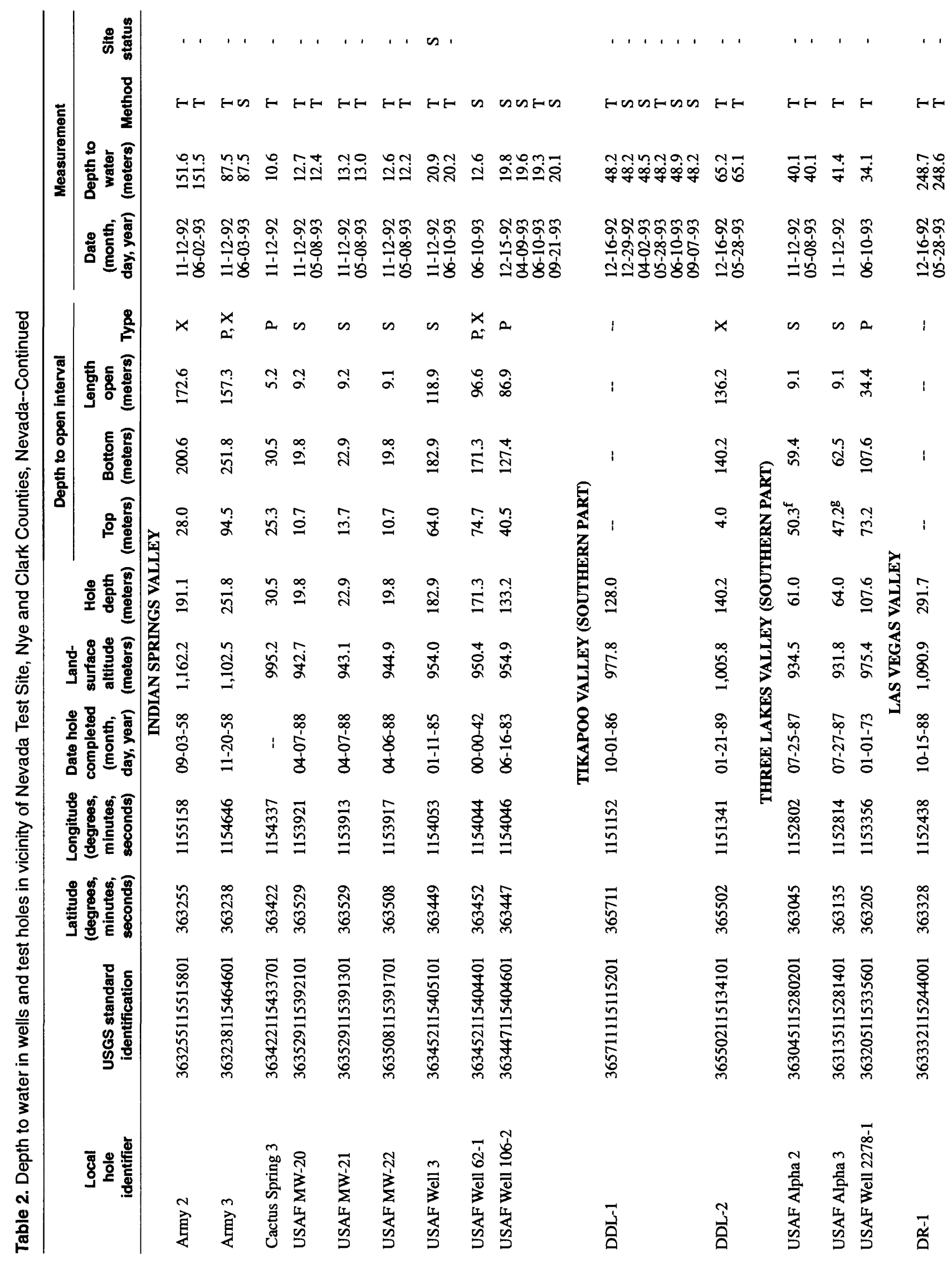




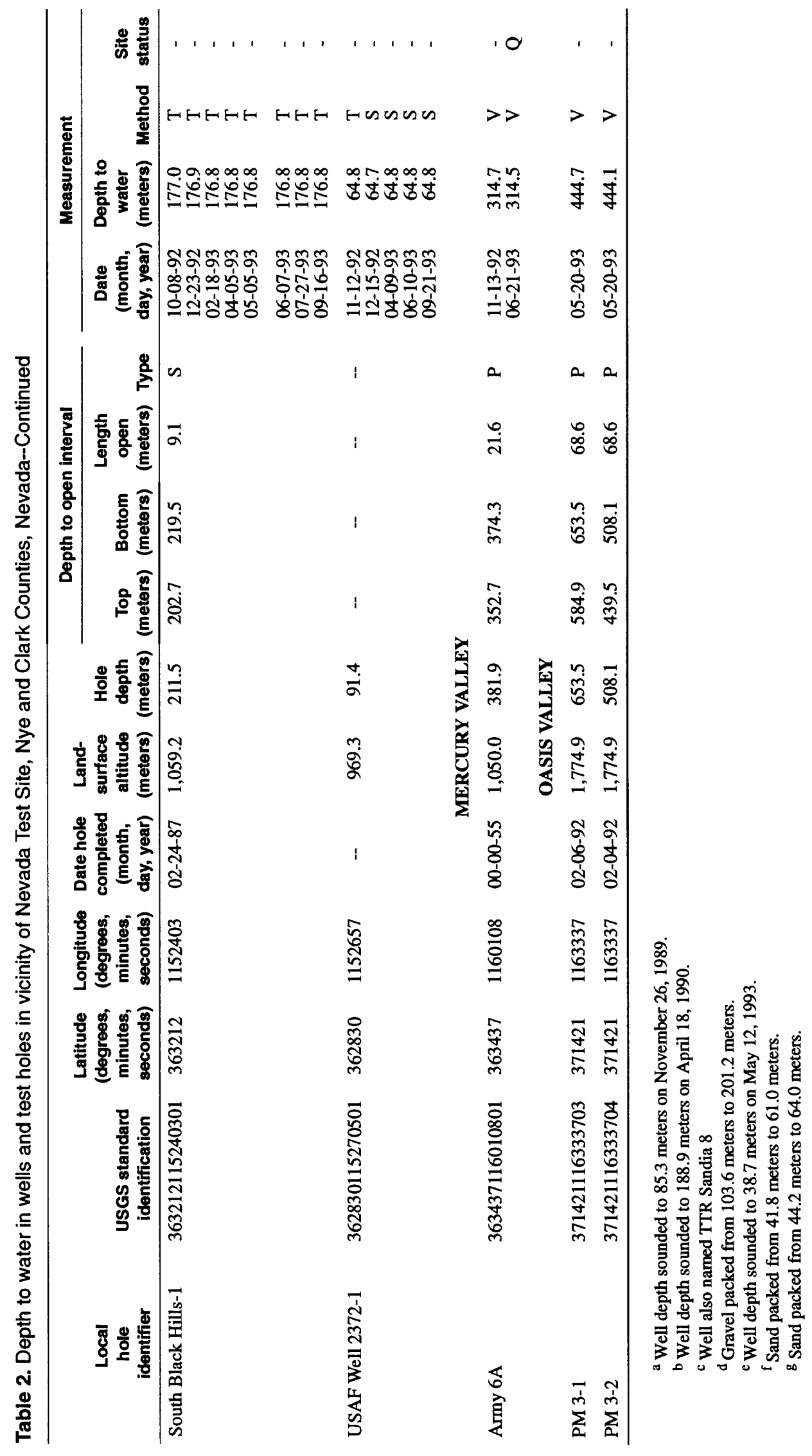




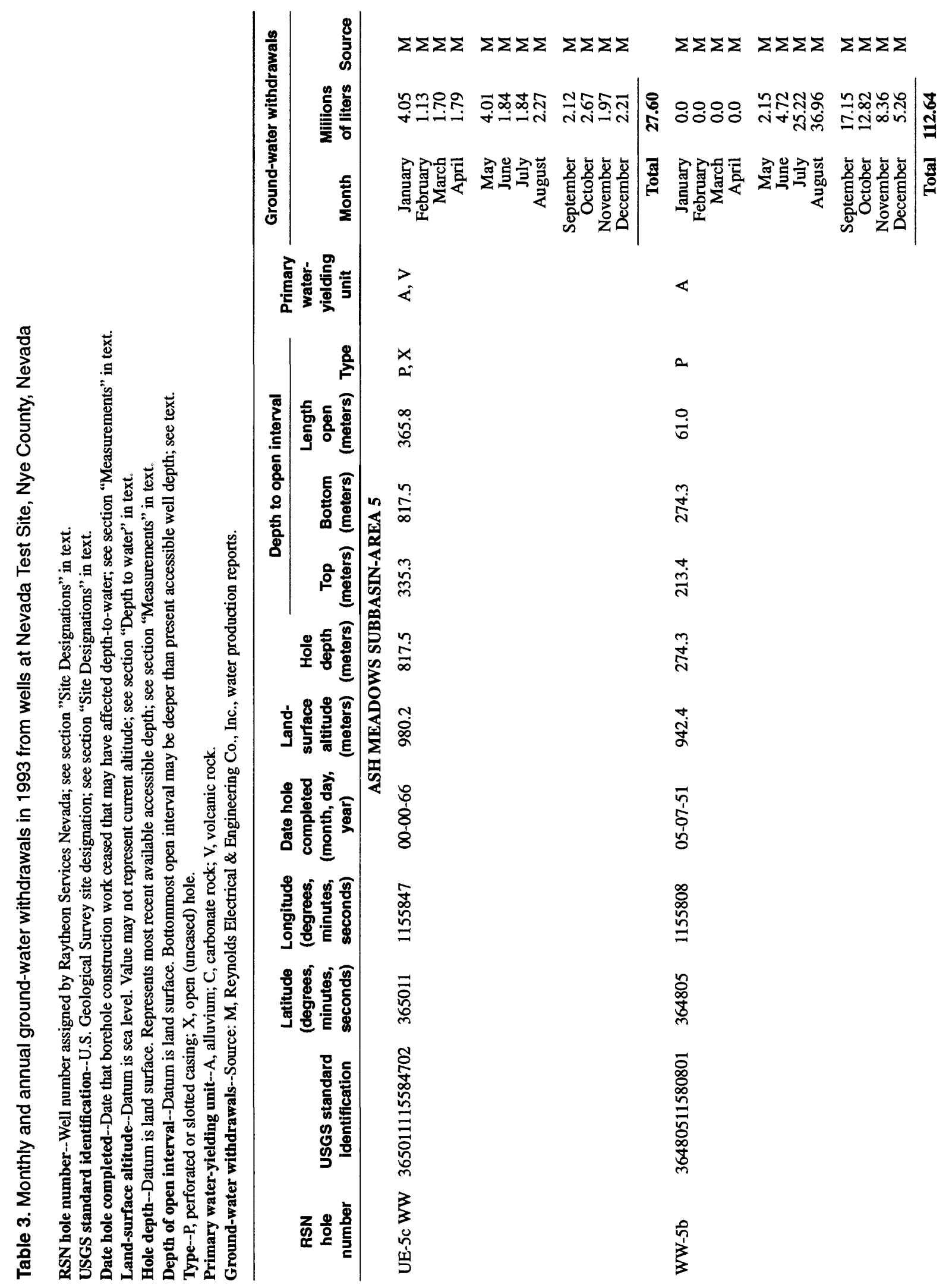




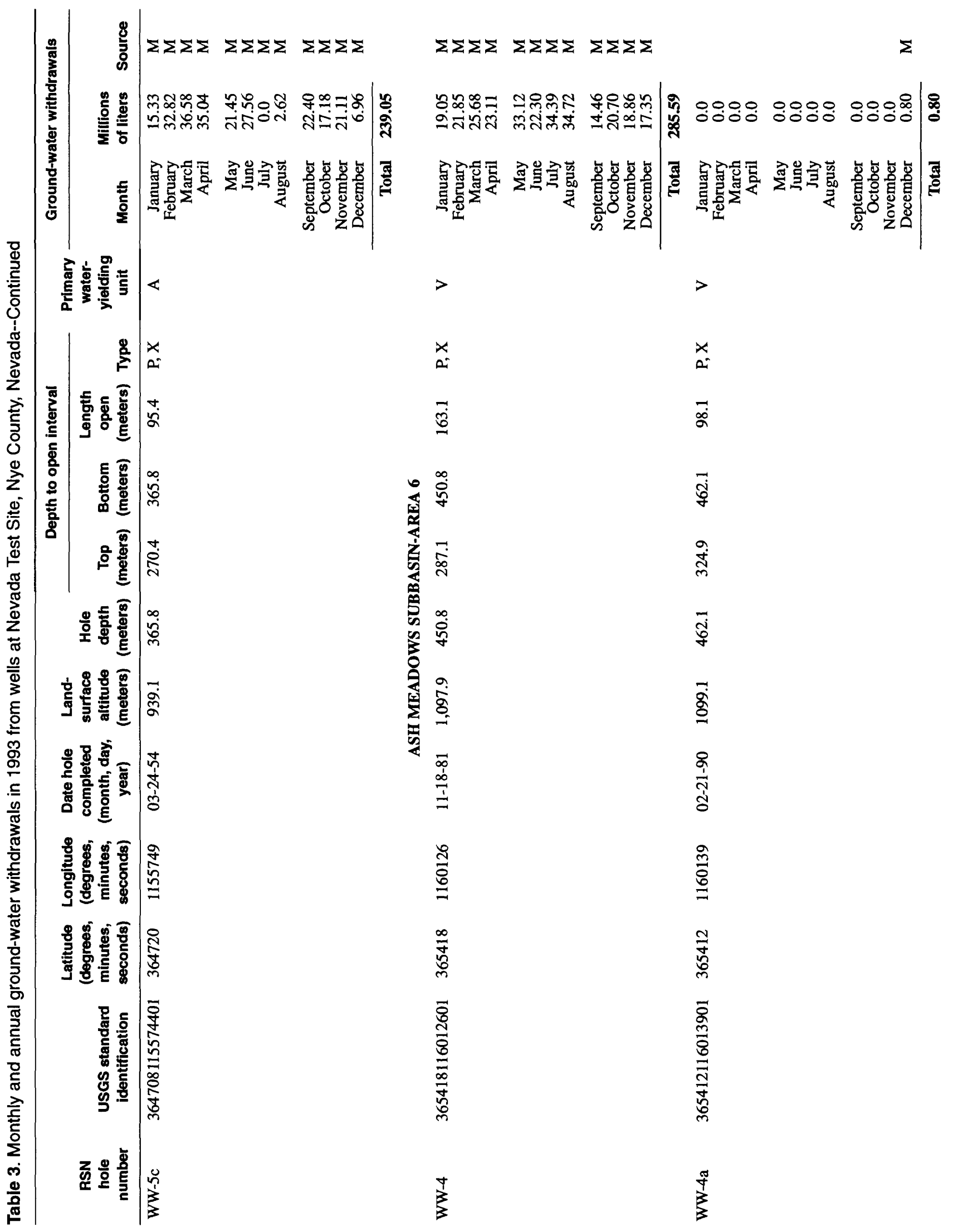




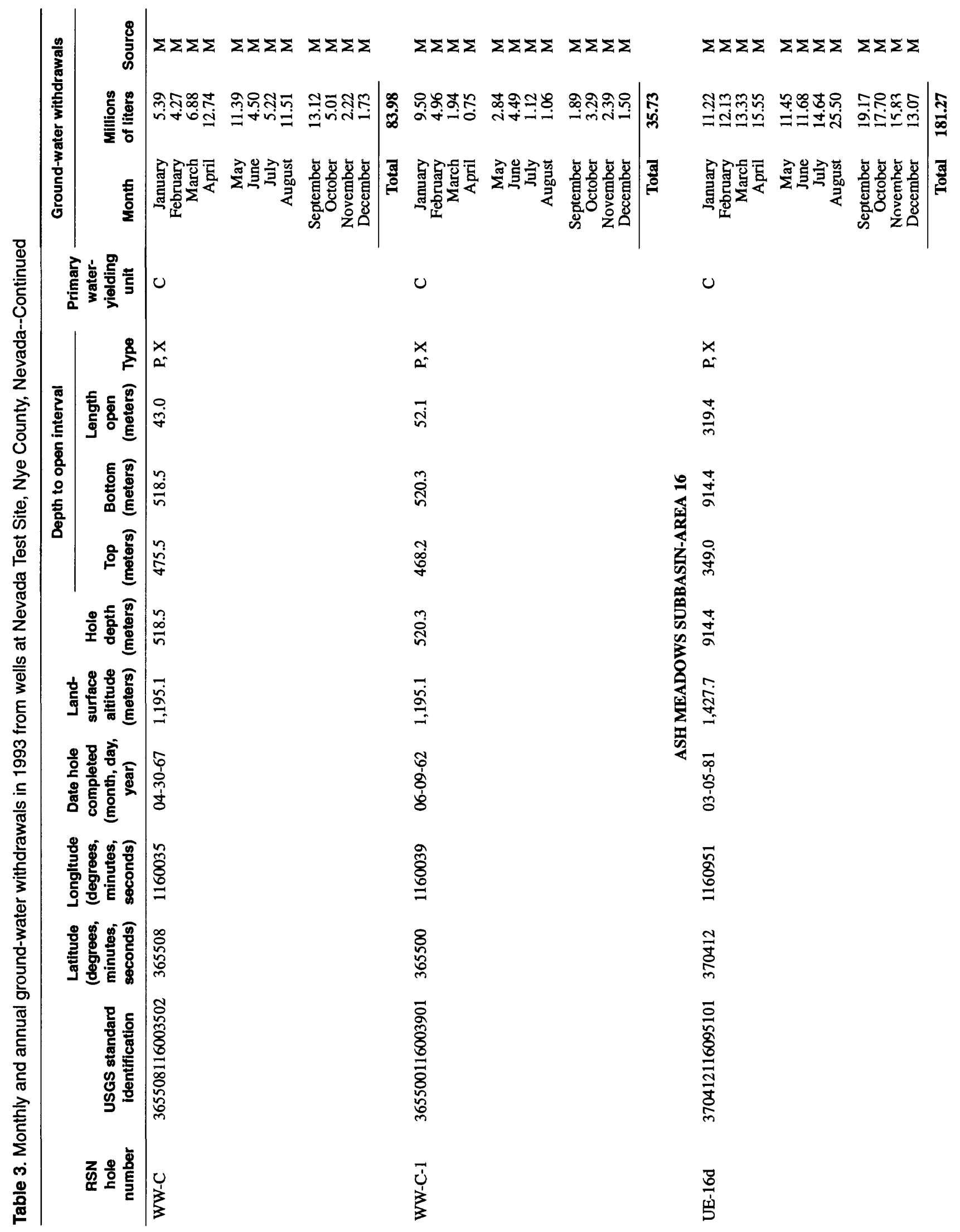




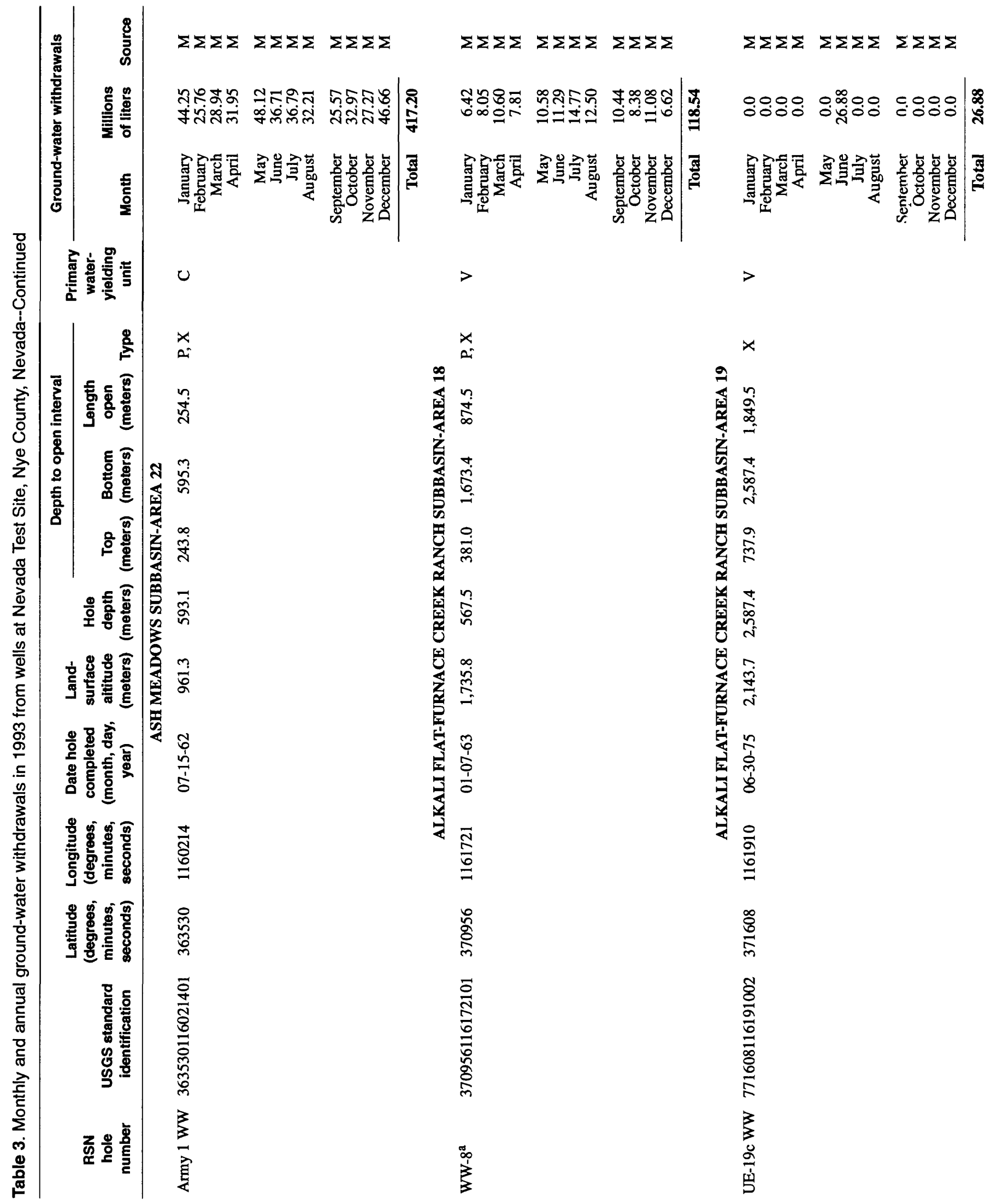




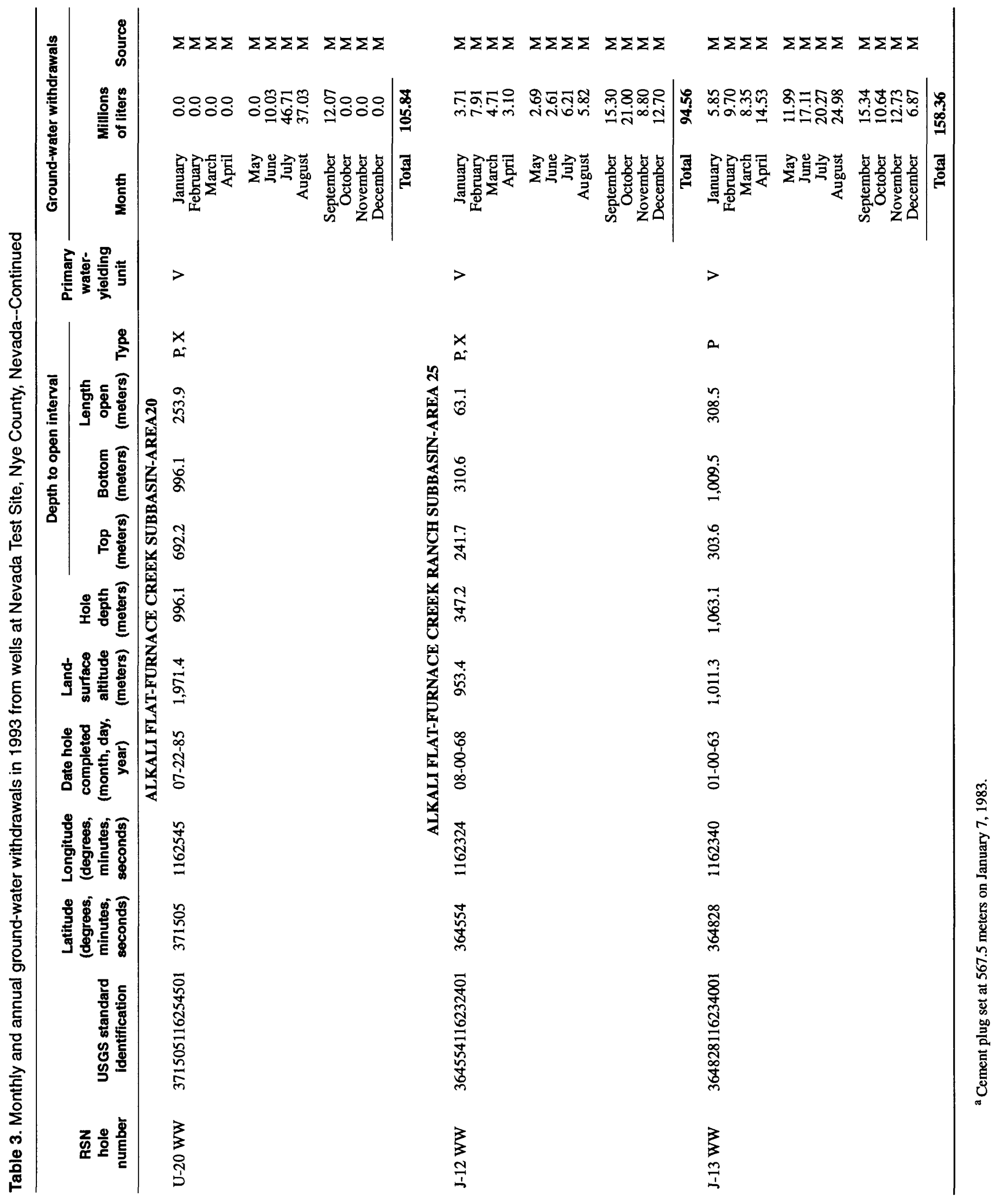




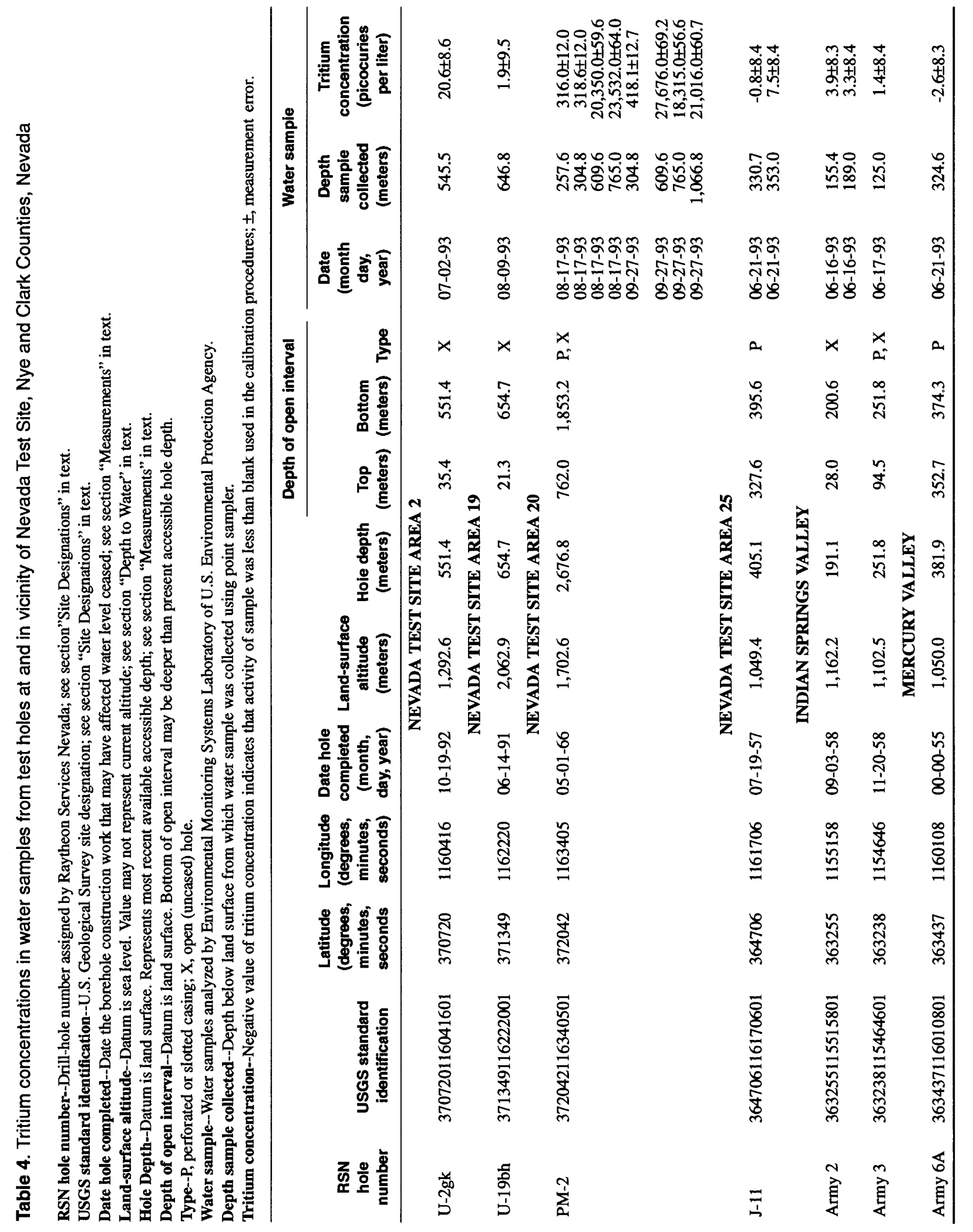

